\title{
Phosphorus cycling and algal-bacterial competition in Sandsfjord, western Norway
}

\author{
T. Frede Thingstad, Evy F. Skjoldal, Rolf A. Bohne
}

Univ, of Bergen, Dept of Microbiology and Plant Physiology, Jahnebk. 5, N-5007 Bergen, Norway

\begin{abstract}
Microbial phosphorus-cycling, with particular emphasis on algal/bacterial competition, was studied in depth profiles through the halocline separating a brackish top layer, rich in nitrate and poor in phosphate, from the underlying coastal water, poor in both nitrate and phosphate, in the Sandsfjord area, western Norway. At 2 stations along the axis of natural freshwater outflow, physiological P-deficiency of algae and bacteria in the brackish layer was inferred from rapid luxury consumption of added $\mathrm{PO}_{4}{ }^{3-}$ by organisms in size fractions $>1 \mu \mathrm{m}$ and $1-0.2 \mu \mathrm{m}$, respectively. In a branch of the fjord without natural freshwater outlets, luxury consumption in the brackish layer was less, and without a clear difference between the 2 water layers. High luxury consumption coincided with short (<30 min) turnover times for $\mathrm{PO}_{4}{ }^{3-}$ and strong bacterial dominance of ${ }^{32} \mathrm{PO}_{4}{ }^{3-}$-uptake, suggesting bacterial superiority as competitors during P-limiting conditions. Estimation of P-specific maximum uptake rate and affinity for $\mathrm{PO}_{4}^{3-}$-uptake from isotope dilution experiments indicated bacterial superiority at low and algal superiority at high concentrations. Although most of the ${ }^{32} \mathrm{p}$ hydrolyzed from added $\gamma-\mathrm{AT}^{32} \mathrm{P}$ was initially liberated as free ${ }^{32} \mathrm{PO}_{4}$, partitioning of incorporated ${ }^{32} \mathrm{P}$ between size fractions $>1 \mu \mathrm{m}$ and $1-0.2 \mu \mathrm{m}$ was found to depend on whether label was added as $\gamma-\mathrm{AT}^{32} \mathrm{P}$ or as ${ }^{32} \mathrm{PO}_{4}{ }^{3-}$, indicating that coupling of uptake to hydrolysis by cell-bound enzymes could modify the outcome of algalbacterial phosphorus competition. Disappearance rate of ${ }^{32} \mathrm{P}$ from the $1-0.2 \mu \mathrm{m}$ size fraction following initial labeling and a subsequent cold chase with $\mathrm{PO}_{4}{ }^{3-}$, was used to estimate the flow-rate of phosphorus through the microbial food web. Combined with measured kinetic constants for $\mathrm{PO}_{4}^{3-}$ uptake, alkaline phosphatases and 5'nucleotidases, a coherent flow-scheme could only be obtained assuming very low $\left(<1 \mathrm{nmol}^{-1}\right)$ concentrations of $\mathrm{PO}_{4}{ }^{3-}$ and nucleotides. Chemically measured concentrations of dissolved organic phosphorus (DOP) more than 2 orders of magnitude above the estimated nucleotide level and with an estimated turnover time of ca $500 \mathrm{~h}$, are consistent with the view that this large Preservoir consists mainly of slowly hydrolyzable polymers.
\end{abstract}

\section{INTRODUCTION}

As osmotrophic organisms, both phytoplankton and bacteria supply their need for phosphorus (P) by uptake of dissolved forms of $P$ through the cell membrane, probably mainly in the form of orthophosphate $\left(\mathrm{PO}_{4}{ }^{3-}\right.$ ) (Cembella et al. 1984a). When $\mathrm{P}$ is in short supply for growth of these organisms, the resulting algal/algal and algal/bacterial competition situation may potentially influence, not only the species composition of the phytoplankton and bacterial communities (Cembella et al. 1984b), but also the fundamental functioning of the microbial ecosystem by shifting the balance between phytoplankton and bacteria (Bratbak \& Thingstad 1985) and the bacterial degradation of organic material (Pengerud et al. 1987). Furthermore, if
$\mathrm{PO}_{4}{ }^{3-}$ is split off from the organic part of dissolved organic forms of phosphorus before uptake, without mechanisms that simultaneously connect the released $\mathrm{PO}_{4}{ }^{3-}$ physically to the cell, the $\mathrm{PO}_{4}{ }^{3-}$ liberated by hydrolysis will mix with the pool of free orthophosphate and the whole competition situation will be centered around a single compound only, i.e. the pool of free $\mathrm{PO}_{4}{ }^{3-}$ (Fig. 1). In this scenario, the roles of phytoplankton and bacteria in the phosphorus cycle will be nearly identical: both trophic groups producing extracellular enzymes that hydrolyze phosphate monoesters (PME), and both competing for the released orthophosphate. It seems meaningless within this conceptual framework to distinguish the 2 groups functionally as consumers and remineralizers of phosphate. The important remaining functional difference would be the energy 


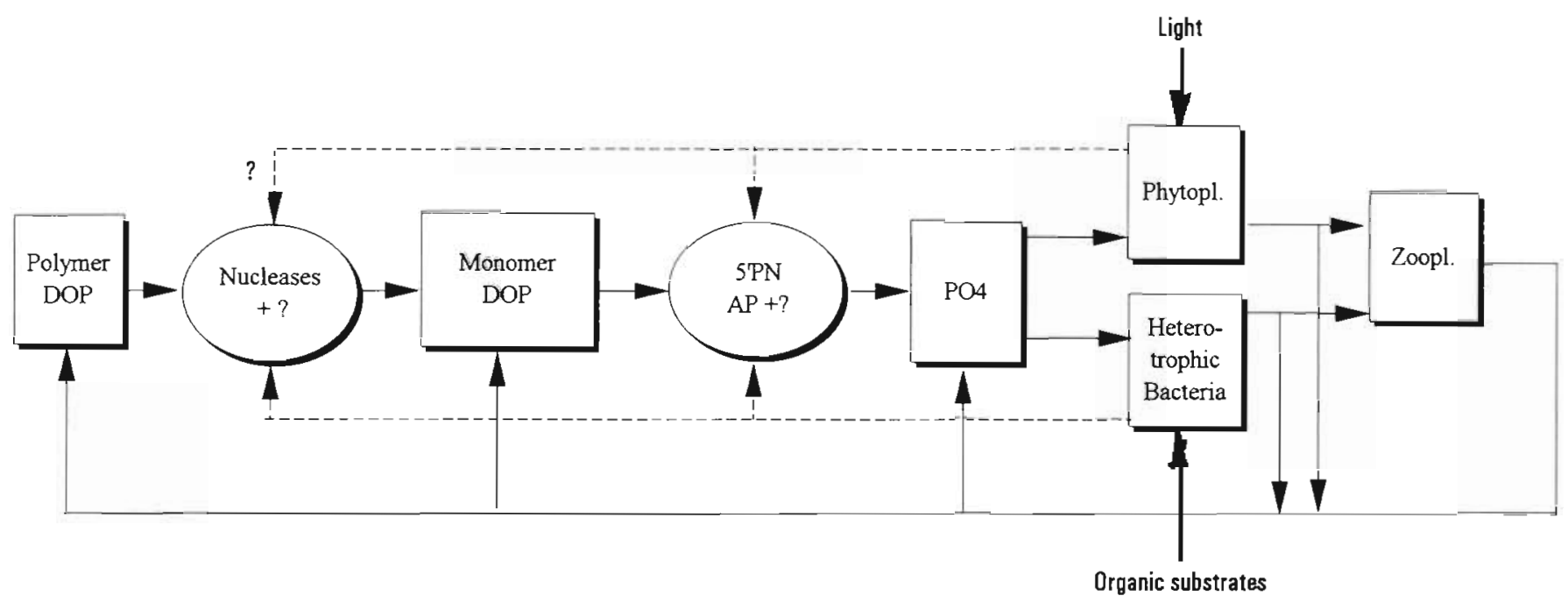

Fig. 1. Idealized flow diagram of microbial P-cycle suggesting a parallel role of algae and bacteria in producing extracellular enzymes for hydrolysis of PDOP and PME and competing for the liberated orthophosphate

source driving the uptake: i.e. light and organic matter respectively.

The idealized flow diagram of Fig. 1 may in reality be complicated by several mechanisms. At least 2 extracellular systems are active in hydrolyzing PME: the alkaline phosphatases (AP) with a general activity towards PME's and therefore presumably relatively insensitive to the organic part of the PME molecules, and the $5^{\prime}$-nucleotidase (5PN) recognizing the organic part of nucleotides and thus active on the nucleotide subset of the PME-pool. Culture studies have revealed both types of enzymes in both algae (Flynn et al. 1986) and bacteria (Bengis-Garber \& Kushner 1981, 1982, McComb et al. 1979), further emphasizing the parallelity in the functioning of the 2 trophic groups. Some studies in natural waters have, however, indicated that 5PN may mainly be associated with the bacterial size fraction (Ammerman \& Azam $(1985,1991$ a). It has also been shown that some of the orthophosphate released by the membrane-bound 5PN may be taken up directly without intermediate mixing into the pool of free orthophosphate (Ammerman \& Azam 1985, 1991a, Tamminen 1989), thus potentially shifting the competition situation for phosphorus in favor of organisms possessing 5PN. A similar situation may exist for AP, although this enzyme is located in the periplasmatic space (Bengis-Garber \& Kushner 1981, Thompson \& McLeod 1974), and not in the membrane as may be the case with 5PN (Bengis-Garber 1985). Liberation of enzymes to the water, either by active processes, by processes such as sloppy feeding or cell lysis, or by osmotic stress in this estuarine environment, would drive the system towards the pure orthophosphate competition indicated in Fig. 1 by preventing hydrolysis-uptake coupling on cell surface cell-bound coupling of hydro- lysis and uptake. Strong bacterial dominance of orthophosphate uptake in some systems has led to speculation as to whether algae supply their need for $\mathrm{P}$ from organic sources (Currie \& Kalff 1984). While the short-term distribution of P-uptake between phytoplankton and bacteria may be seen as a function of the uptake kinetics, the relative biomasses of the 2 populations, and the concentration of available substrates, other factors such as energy availability and biomass loss through predation or other factors may modify the competition in the long-term.

In the work presented here, we have attempted to map qualitatively and quantitatively the microbial transformation of phosphorus in the top layer of the Sandsfjord system of freshwater-influenced fjords on the southwestern coast of Norway (Fig. 2). The upper, brackish layer of this system is characterized by a high nitrate: phosphate ratio reflecting the chemical characteristics of the freshwater discharges from rivers and from a major hydroelectric power plant (Aure \& Rey 1992). The potential P-limitation in this fjord has also been of particular interest since it has experienced regular summer blooms since 1989 of the toxic prymnesiophyte Prymnesium parvum (Kaartvedt et al. 1991. Aure \& Rey 1992) inflicting economic losses on fish farming industries in the fjord. The toxicity of this alga is known to increase under P-limitation (Shilo 1967), potentially explaining its ecological success in this fjord system.

\section{MATERIAL AND METHODS}

Study area. The study area (Fig. 2) is a narrow fjord system on the southern part of the Norwegian west coast. Details of its topography and hydrography and 


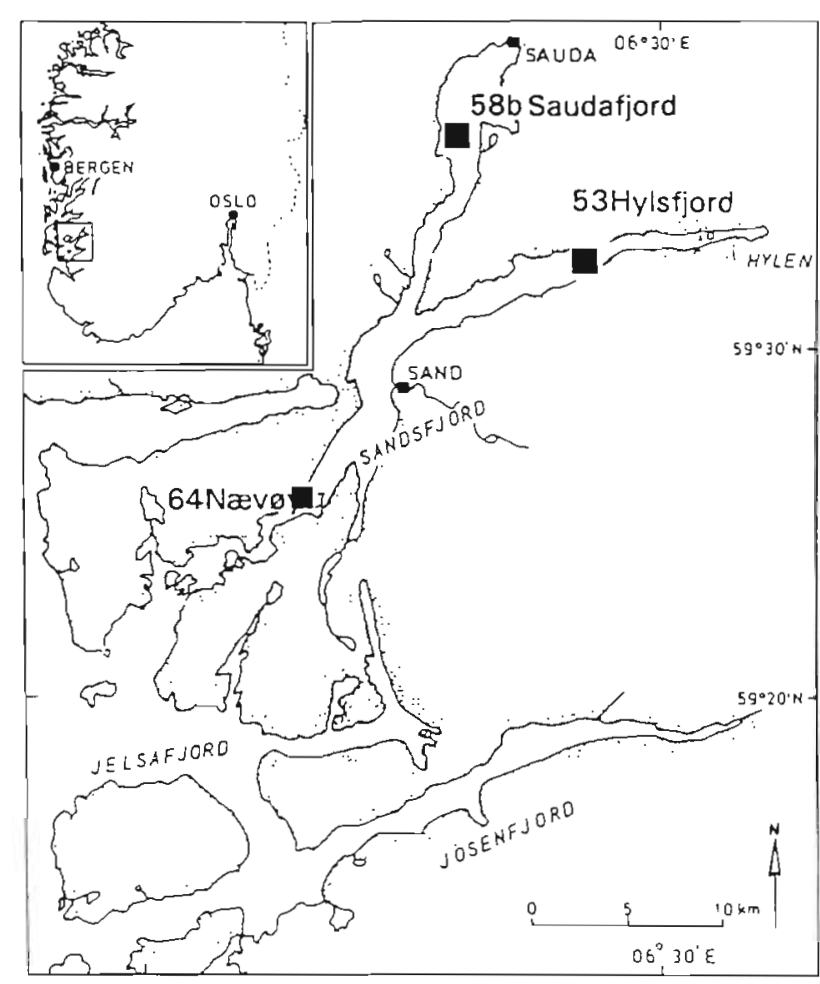

Fig. 2. The Sandsfjord system, southwestern Norway, showing the 3 sampling Stns 53,58 b \& 64 , the natural river freshwater release positions at Sand and Sauda, and the hydroelectric power plant at Hylen

the hydrographical effects of the hydroelectric power plant at Hylen are described by Aure \& Rey (1992). When the hydroelectric power plant is shut off, as it was until July 31 during the investigation presented here, the estuarine circulation is dominated by the freshwater outlets from rivers at Sauda and Sand, creating a ca $5 \mathrm{~m}$ deep brackish layer separated by a steep halocline from the underlying coastal water. The main freshwater outflow is then along the axis Saudafjord-Sandsfjord-Nævøy. When the hydroelectric power plant at Hylen is running, it releases cold freshwater which mixes into an intermediate layer creating inward compensation currents above and below in the Hylsfjord branch (Aure \& Rey 1992).

Sampling. The investigations reported here were done in the period July 28 to August 2, 1992, on a cruise with RV 'Håkon Mosby'. Samples were collected using Niskin bottles. The water was prefiltered through a $180 \mu \mathrm{m}$ nylon screen, and stored in rinsed polyethylene carboys. Sample treatment took place within $2 \mathrm{~h}$ of collection. Samples for this study were collected at Nævøy (Stn 64), in the Hylsfjord (Stn 53), and in the Saudafjord (Stn 58b) (Fig.2).

Incubation. Except for the cold chase experiment where 1 l polyethylene bottles were used, incubations for experiments with ${ }^{32} \mathrm{P}$ were done in $10 \mathrm{ml}$ subsamples in $20 \mathrm{ml}$ polyethylene scintillation vials at approximately in situ temperature and light. Incubations were stopped by cold chase using a $100 \mu \mathrm{l}$ addition of $10 \mathrm{mmol} \mathrm{l}^{-1} \mathrm{KH}_{2} \mathrm{PO}_{4}\left(0.1 \mathrm{mmol} \mathrm{l^{-1 }}\right.$ final conc.) to experiments with ${ }^{32} \mathrm{PO}_{4}^{3}$ and an additional $100 \mu \mathrm{l}$ of $10 \mathrm{mmol} \mathrm{l}^{-1}$ ATP (Sigma) $\left(0.1 \mathrm{mmol} \mathrm{l}^{-1}\right.$ final conc.) to experiments with $\gamma$-AT ${ }^{32}$ P. Filtrations were finished within 30 min after the addition of cold chase.

Filtrations. All filtrations were done on polycarbonate filters. Filtrations for ${ }^{32} \mathrm{P}$-studies were done as serial filtrations except for the cold chase experiment where filtrations were done in parallel. A Millipore manifold holding 12 filters of $25 \mathrm{~mm}$ was used. Vacuum was kept low: $<0.05$ bar for $1 \mu \mathrm{m}$ or larger pore sized filters, and $<0.2$ bar for $0.2 \mu \mathrm{m}$ filters. Filters were washed with $3 \times 1 \mathrm{ml}$ filtered seawater. Unless otherwise indicated, whole water samples were postfractionated. For prefractionation, samples were filtered on $47 \mathrm{~mm}$ polycarbonate filters. Material for determination of particulate-P and chlorophyll in size fractions was obtained by serial filtration on $47 \mathrm{~mm}$ polycarbonate filters mounted in filtration 'towers' (Nuclepore). Suction $<0.2$ bar was applied below the $0.2 \mu \mathrm{m}$ filter In this setup, the slow flow rate through the $0.2 \mu \mathrm{m}$ filter controls the flow through the larger pore-sized filters above.

Measurement of radioactivity. Cerenkov radiation from ${ }^{32} \mathrm{P}$ was counted in $10 \mathrm{ml}$ water in polyethylene scintillation vials using a Packard Tri-Carb scintillation spectrometer. Added radioactivity was measured in a parallel sample in all experiments. Blanks were subtracted and all values calculated as \% of added activity.

Uptake of ${ }^{32} \mathrm{PO}_{4}{ }^{3-}$. Carrier-free ${ }^{32} \mathrm{P}$-orthophosphate was diluted in quartz-distilled water, filtered on prewashed $0.2 \mu \mathrm{m}$ filters immediately before use, and added to give a total count of approximately $1 \times 10^{6}$ $\mathrm{min}^{-1}$ per $10 \mathrm{ml}$ sample ( $\max 100 \mu \mathrm{l} / 10 \mathrm{ml}$ sample). Blanks were obtained using filtered formaldehyde $(50 \mu \mathrm{l} 25 \% / 10 \mathrm{ml})$. For isotope dilution experiments, orthophosphate was added to the given final concentrations as $\mathrm{KH}_{2} \mathrm{PO}_{4}$ in quartz-distilled water (max $100 \mu \mathrm{l}$ per $10 \mathrm{ml}$ sample). Unless otherwise stated, samples were incubated for $15 \mathrm{~min}$.

Hydrolysis of $\gamma-\mathrm{AT}^{32} \mathrm{P}$. Hydrolysis of $\gamma-\mathrm{AT}^{32} \mathrm{P}$ was measured according to Ammerman \& Azam (1985). Nearly carrier-free isotope (111 TBq $\left.\mathrm{mmol}^{-1}\right)$ was added to a final concentration of $40 \mathrm{pmol}^{-1}$. In isotope dilution experiments, preweighed ATP (Sigma) was dissolved in sterile quartz-distilled water immediately before use and added to the desired final concentration ( $\max 100 \mu \mathrm{l}$ per $10 \mathrm{ml}$ sample). Hydrolysis due to alkaline phosphatase activity (APA) and 5'-nucleotidase activity (5PNA) were computed as removed and remaining activity respectively, following competitive in- 
hibition of APA by addition of $10 \mu \mathrm{mol} \mathrm{l}^{-1}$ final concentration of glucose-6-phosphate (G6P). Cell-bound and dissolved hydrolytic activities were separated by prefiltration on polycarbonate filters and uptake of hydrolyzed ${ }^{32} \mathrm{P}$-orthophosphate by postfractionation. Unless otherwise stated, samples were incubated for $30 \mathrm{~min}$. The distribution of label between fractions is given directly without any correction for secondary incorporation of label primarily released as ${ }^{32} \mathrm{PO}_{4}{ }^{3-}$.

Alkaline Phosphatase Activity (APA). APA was measured fluorometrically using methyl-fluoresceinphosphate (MFP) as substrate according to Perry (1972). Different concentrations of the substrate were obtained by diluting the working solution in $0.1 \mathrm{M}$ Trizma- $\mathrm{HCl} \mathrm{pH} 8.5$ and adding $0.5 \mathrm{ml}$ substrate to $4 \mathrm{ml}$ sample in all cases. Fluorescence was measured using a Perkin Elmer LS5 luminescence spectrometer. Samples were incubated for $30 \mathrm{~min}$.

Chemical measurements of phosphate and nitrate. DOP was measured in duplicate on $0.2 \mu \mathrm{m}$ filtrates by wet oxidation in acid persulphate as described by Koroleff (1976) modified to a volume of $10 \mathrm{ml}$ and using polycarbonate tubes with polypropylene caps. Orthophosphate liberated was measured on the standard orthophosphate channel of the autoanalyzer. For particulate-P, triplicate samples of 200 to $250 \mathrm{ml}$ were filtered. Filters were submerged in $10 \mathrm{ml}$ quartz-distilled water in polycarbonate tubes and wet oxidized as for DOP. Blanks with filters were subtracted. Soluble reactive phosphorus (SRP) was measured on the autoanalyzer after a $5 \times$ concentration using the magnesium hydroxide precipitation method of Karl \& Tien (1992) with $\mathrm{MgCl}_{2}\left(10 \mathrm{mmol} \mathrm{l}^{-1}\right.$ final conc.) added. Nitrate was measured by standard methods on the autoanalyzer.

'Luxury consumption' of orthophosphate. We added $0.8 \mathrm{ml} \mathrm{KH}_{2} \mathrm{PO}_{4}\left(10 \mu \mathrm{mol} \mathrm{ml} l^{-1}\right)$ to $800 \mathrm{ml}$ of sample (10 $\mu \mathrm{mol} \mathrm{l}^{-1}$ final conc.) and determined particulate-P in triplicate after $1 \mathrm{~h}$ incubation of the orthophosphateenriched sample in $1 \mathrm{l}$ polyethylene bottles. 'Luxury consumption' was calculated as increase after incubation in particulate- $P$ as $\%$ of particulate- $P$ in the original sample.

Cold chase experiment. Advantage was taken of the short turnover time for orthophosphate in the brackish layer. This allowed rapid labelling of the natural populations of algae and bacteria without extensive handling of the organisms. Carrier-free ${ }^{32} \mathrm{PO}_{4}{ }^{3-}$ was added to two $1 \mathrm{l}$ subsamples. These were incubated in 11 polyethylene bottles and at intervals, $10 \mathrm{ml}$ aliquots were filtered (in parallel) on 10, 5, 1, and $0.2 \mu \mathrm{m}$ poresized polycarbonate filters. The filtrate from the $0.2 \mu \mathrm{m}$ filtration was treated with acid and active charcoal to separate label in DOP from that in orthophosphate as described by Ammerman \& Azam (1985). To prevent reassimilation of recycled orthophosphate, one of the incubation bottles was given a 'cold chase' of $10 \mu \mathrm{mol}$ $\mathrm{l}^{-1}$ (final conc.) $\mathrm{KH}_{2} \mathrm{PO}_{4} 1.5 \mathrm{~h}$ after the addition of label.

Chlorophyll. Samples of 200 to $250 \mathrm{ml}$ were filtered on $47 \mathrm{~mm}$ polycarbonate for fluorometric chlorophyll a determination (Holm-Hansen \& Riemann 1978) on a Turner Designs fluorometer using $24 \mathrm{~h}$ extraction in $90 \%$ acetone and correction for phaeophytins by acidification.

Bacterial enumeration. DAPI-stained bacteria (Porter \& Feig 1980) were counted using epifluorescence microscopy. Formalin-fixed samples of 50 and $5 \mathrm{ml}$ were filtered (in parallel) immediately after fixation on 1 and $0.2 \mu \mathrm{m}$ pore size, $25 \mathrm{~mm}$ diameter polycarbonate filters prestained with Irgalan Black. Preparations were observed at $1000 \times$ magnification using UV excitation on a Zeiss Standard microscope.

Estimation of $V^{\mathrm{m}}$ and $K+S_{\mathrm{n}}$ and $T$. The consumed fraction $R(t)$ of added label after an incubation time was assumed to follow the theoretical expression (symbols summarized in Table 1):

$$
R(t)=\left(1-\mathrm{e}^{-t / T_{a}}\right)
$$

where $T_{\mathrm{a}}=\left(S_{\mathrm{n}}+S_{\mathrm{a}}\right) / v$ is the turnover time in the sample with added and natural substrate concentration $S_{a}$ and $S_{n}$ respectively; $v$ is the velocity of the reaction. The radioactivity $r_{1}$ in fraction $i$ resulting from primary uptake (excluding secondary transfer between compartments due to grazing etc.) then follows:

$$
r_{i}(t)=\alpha_{i}\left(1-e^{-t / T_{\alpha}}\right)
$$

Table 1. Abbreviations and symbols used

$\begin{array}{ll}\text { AP(A) } & \text { Alkaline phosphatase (activity) } \\ \text { 5PN(A) } & \text { 5'Nucleotidase (activity) } \\ \text { DOP } & \text { Dissolved organic phosphorus } \\ \text { PME } & \text { Phosphate monoesters } \\ \text { PP } & \text { Particulate phosphorus } \\ \text { SRP } & \text { Soluble reactive phosphorus } \\ \text { MFP } & \text { Methyl-fluorescein-phosphate } \\ V^{m} & \text { Maximum velocity } \\ K & \text { Half saturation constant } \\ T & \text { Turnover time defined as concentration of sub- } \\ & \text { strate divided by rate of removal process; } \\ & \text { subscript 'a' to denote turnover time in samples } \\ & \text { with extra addition of substrate; subscripts PO } \\ & \text { 5PNA+APA, and APA to } V^{m}, K \text { and T used to in- } \\ & \text { dicate parameters related to uptake of ortho- } \\ & \text { phosphate, hydrolysis of ATP by APA and } 5 \text { PNA } \\ & \text { together, and hydrolysis of MFP by APA alone } \\ S_{\mathrm{n}} & \text { Natural substrate concentration } \\ S_{\mathrm{d}} & \text { Added substrate concentration } \\ \alpha_{1} & \text { Fraction of uptake in compartment } i \\ R(t) & \text { Fraction of added label consumed after } \\ & \text { incubation time } t \\ I_{i}(t) & \text { Fraction of added label taken up by size } \\ & \text { fraction } i \text { after incubation time } t\end{array}$


where $\alpha_{i}$ is the fraction of total uptake going into size fraction $i$. From experiments with single incubation times, the turnover time $T_{d}$ of substrate in the incubation bottle (with or without added substrate) was computed from the rearranged Eq. (1):

$$
T_{\mathrm{a}}=\frac{t}{-\ln (1-R)}
$$

Following the principle developed by Wright \& Hobbie (1966), the equation of an assumed MichaelisMenten kinetics with half-saturation constant $K$ and maximum reaction velocity $V^{\mathrm{m}}$ can be rearranged to:

$$
T_{\mathrm{a}}=\frac{\left(K+s_{\mathrm{n}}\right)}{V^{\mathrm{m}}}+\frac{s_{\mathrm{a}}}{V^{\mathrm{m}}}
$$

If Michaelis-Menten kinetics is obeyed, plotting of measured $T_{\mathrm{a}}$ values vs a series of added substrate concentrations should therefore give a straight line from which:

(1) Turnover time $T$ in unamended water sample can be estimated as the crossing point with the $y$-axis $\left(S_{\mathrm{a}}=0\right)$,

(2) Maximum reaction velocity $V^{m}$ can be estimated as the inverse of the slope, and

(3) The sum of the half-saturation constant plus the natural substrate concentration $K+S_{n}$ can be estimated by extrapolation to the crossing point with the $x$-axis.

This procedure was used for alkaline phosphatase activity, 5'-nucleotidase activity and for orthophosphate uptake in the size fractions $>1 \mu \mathrm{m}$ and $1-0.2 \mu \mathrm{m}$; lines were fitted by least squares regression, and $\mathrm{R}^{2}$-values are given to indicate the goodness of fit of the original data to the assumed model. For low $\mathrm{R}^{2}$-values, the standard error of the $K+S_{\mathrm{n}}$ becomes particularly large due to the extrapolation of the line outside the set of actual $S_{\mathrm{d}}$ values.

\section{RESULTS}

\section{Nutrients and hydrography}

At all 3 stations investigated, there was a mixed brackish layer down to approximately $3 \mathrm{~m}$ with salinities $<4.5$ psu, separated from the underlying water by a steep halocline with salinities $>25$ psu from ca $5 \mathrm{~m}$. Stn 58b in Saudafjord had a less saline brackish layer (ca 2 psu) than the 2 other stations ( 3 to 4.5 psu). Little change was found in salinity profiles between July 28 and August 2 , but the water released from the hydroelectric power plant at Hylen from August 31 could be identified as a narrow, low-temperature layer in the

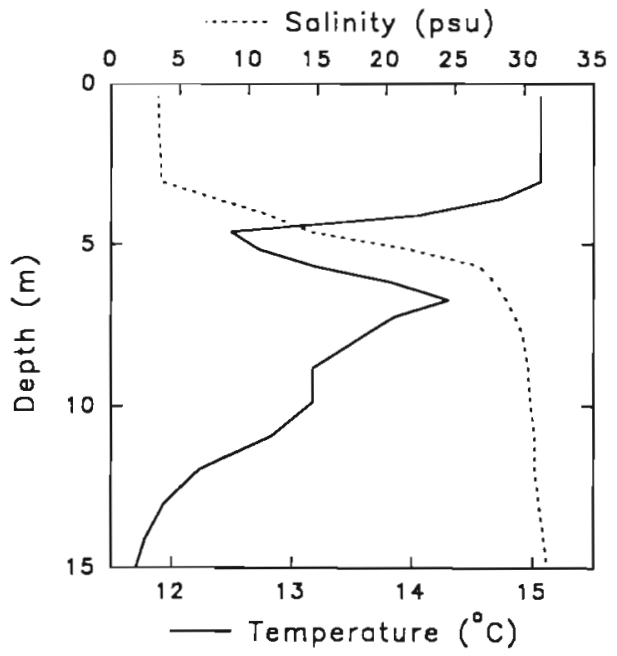

Fig. 3. Hydrographical profiles at Stn 53 in Hylsfjord on August 2, 1992. The particular feature at this station, of power plant water released from July 31 at Hylen, can be identified by the low temperature anomaly in the halocline

halocline (Fig. 3), not present at the other stations and dates. Nitrate levels in the brackish layer were relatively high, 6 to $8 \mu \mathrm{mol} \mathrm{l}^{-1}$, at Stns 64 (Nævøy) and 58b (Saudafjord), and somewhat lower, 2 to $4 \mu \mathrm{mol} \mathrm{l}^{-1}$, at Stn 53 (Hylsfjord). Below the halocline nitrate levels decreased, with values from 0.6 to $0.07 \mu^{m o l ~ l^{-1}}$ at $10 \mathrm{~m}$. Except for Stn 58b on August 2, SRP values in the brackish layer were $<25 \mathrm{nmol}^{-1}$, generally with a tendency towards slight increase below the pycknocline to values in the range 18 to 59 at $10 \mathrm{~m}$ (Table 2). Total phosphorus (sum of all fractions) varied from 300 to $600 \mathrm{nmol} \mathrm{l}^{-1}$. As a mean, $46 \%$ of the phosphorus was found as DOP, with a tendency towards higher ( $>70 \%)$ values at Stn 64 (Nævøy).

Most of the particulate phosphorus was invariably found in the size fraction $>1 \mu \mathrm{m}$ (Table 2 ). When this size fraction was split into the classes $>10,10-5$, and 5-1 $\mu \mathrm{m}$ (Hylsfjord July 30), particulate phosphorus was dominated by the $>10 \mu \mathrm{m}$ fraction at both 2 and 10 m (Fig. 4a).

Size fractionation of chlorophyll (Fig. 4b) from the same samples resulted in only minor amounts of chlorophyll passing into the $1-0.2 \mu \mathrm{m}$ size fraction $(1.2 \%$ and $3.5 \%$ respectively at 2 and $10 \mathrm{~m}$ ). For 2 and $10 \mathrm{~m}$, 7 and $6 \%$ respectively of the bacteria were retained by the $1 \mu \mathrm{m}$ filter, confirming previous (unpublished) results from the same area that $<10 \%$ of the chlorophyll and $>90 \%$ of the bacteria will normally pass a $1 \mu \mathrm{m}$ pore-sized polycarbonate filter in these waters

The dominance of the $1-5 \mu \mathrm{m}$ size class seen in the chlorophyll distribution at $2 \mathrm{~m}$ (Fig. $4 \mathrm{~b}$ ) is not reflected to the same degree in the phosphorus distribution (Fig. 4a). This shift towards higher size classes in 
Table 2. Phosphate concentrations (nmol $i^{-1}$ ) in the tractions SRP, DOP, and particulate-P (PP) in the fractions $>1 \mu \mathrm{m}$ and $1-0.2 \mu \mathrm{m}$ above $(0,5$ and $2 \mathrm{~m})$, in $(5 \mathrm{~m})$, and below $(10 \mathrm{~m})$ the halocline at Stns 58b, 64, and 53 on July 28 and August 2,1992

\begin{tabular}{|c|c|c|c|c|c|c|c|c|c|c|c|c|}
\hline \multirow[t]{2}{*}{ Stn } & \multirow[t]{2}{*}{ Date } & \multirow{2}{*}{$\begin{array}{l}\text { Depth } \\
\text { (m) }\end{array}$} & \multicolumn{2}{|c|}{ SRP } & \multicolumn{2}{|c|}{ DOP } & \multicolumn{2}{|c|}{$\mathrm{PP} 1-0.2 \mu \mathrm{m}$} & \multicolumn{2}{|c|}{$\mathrm{PP}>1 \mu \mathrm{m}$} & \multicolumn{2}{|c|}{ Total P } \\
\hline & & & Mean & $\begin{array}{c}\text { SE } \\
\mathrm{n}=3\end{array}$ & Mean & $\begin{array}{c}1 / 2-\text { Range } \\
n=2\end{array}$ & Mean & $\begin{array}{c}\mathrm{SE} \\
\mathrm{n}=3\end{array}$ & Mean & $\begin{array}{c}\mathrm{SE} \\
\mathrm{n}=3\end{array}$ & $\begin{array}{l}\text { Sum of } \\
\text { all fractions }\end{array}$ & $\mathrm{SE}$ \\
\hline \multirow{8}{*}{$\begin{array}{l}\text { Stn 58b } \\
\text { Saudafjord }\end{array}$} & Jul 28 & 0.5 & 14 & 2 & 256 & NA & 40 & 1 & 126 & 23 & 436 & 23 \\
\hline & & 2 & -3 & 0 & 283 & NA & 33 & 1. & 69 & 9 & 381 & 9 \\
\hline & & 5 & 88 & 4 & 112 & 10 & 68 & 18 & 261 & 3 & 529 & 21 \\
\hline & & 10 & 46 & $i$ & 304 & 110 & 41 & 5 & 180 & 8 & 571 & 110 \\
\hline & Aug 2 & 0.5 & 49 & 2 & 121 & 20 & 27 & 8 & 1.06 & 3 & 303 & 22 \\
\hline & & 2 & 66 & 8 & 104 & NA & 32 & 3 & 103 & 8 & 304 & 12 \\
\hline & & 5 & 49 & NA & 186 & 15 & 61 & 6 & 264 & 16 & 560 & 23 \\
\hline & & 10 & 59 & 13 & 161 & 10 & 37 & 3 & 148 & 14 & 405 & 22 \\
\hline \multicolumn{3}{|c|}{ Mean and SD; Stn 58b } & 46 & 29 & 191 & 80 & 42 & 15 & 157 & 73 & 436 & 108 \\
\hline \multirow{8}{*}{$\begin{array}{l}\text { Stn } 64 \\
\text { Naevøy }\end{array}$} & Jul 28 & 0.5 & 16 & 1 & 224 & 0 & 53 & 22 & 64 & 14 & 358 & 26 \\
\hline & & 2 & 10 & 3 & 245 & 5 & NA & NA & NA & NA & $\mathrm{NA}$ & NA \\
\hline & & 5 & 16 & 6 & 274 & 0 & NA & NA & 86 & NA & NA & NA \\
\hline & & 10 & 18 & 1 & 337 & 35 & NA & NA & 73 & 5 & NA & NA \\
\hline & Aug 2 & 0.5 & 6 & 1 & 364 & 20 & 42 & 3 & 90 & 9 & 502 & 22 \\
\hline & & 2 & 14 & 1 & 391 & 45 & 37 & 8 & 101 & 2 & 543 & 46 \\
\hline & & 5 & 20 & 1 & 310 & 0 & 41 & 5 & 84 & 2 & 455 & 5 \\
\hline & & 10 & 37 & 0 & 318 & 15 & 27 & 1 & 64 & 11 & 446 & 18 \\
\hline \multicolumn{3}{|c|}{ Mean and SD; Stn 64} & 17 & 9 & 308 & 58 & 37 & 9 & 83 & 14 & 486 & 70 \\
\hline \multirow{8}{*}{$\begin{array}{l}\text { Stn } 53 \\
\text { Hylsfjord }\end{array}$} & Jul 28 & 0.5 & 5 & 0 & 220 & 25 & 36 & 10 & 126 & 1 & 386 & 27 \\
\hline & & 2 & 1 & 0 & 244 & 25 & 42 & 3 & 129 & 5 & 417 & 26 \\
\hline & & 5 & 2 & 1 & 133 & 25 & 40 & 5 & 125 & 6 & 301. & 26 \\
\hline & & 10 & 27 & 0 & 188 & 5 & 50 & 7 & 140 & 12 & 405 & 14 \\
\hline & Aug 2 & 0.5 & 22 & 3 & 158 & 30 & 40 & 1 & 207 & 9 & 427 & 31 \\
\hline & & 2 & 17 & 1 & 233 & 0 & 37 & 1 & 195 & 11 & 483 & 12 \\
\hline & & 5 & 39 & 0 & 271 & 0 & 49 & 10 & 227 & 16 & 586 & 19 \\
\hline & & 10 & 40 & 1 & 250 & 10 & 28 & 5 & 120 & 10 & 438 & 15 \\
\hline \multicolumn{3}{|c|}{ Mean and SD; Stn 53} & 19 & 16 & 212 & 48 & 40 & 7 & 159 & 44 & 430 & 82 \\
\hline \multirow{3}{*}{\multicolumn{2}{|c|}{$\begin{array}{r}\text { Mean and SD; } \\
\text { all stations }\end{array}$}} & $0.5 \& 2$ & 18 & 20 & 237 & 85 & 38 & 7 & 120 & 46 & 413 & 77 \\
\hline & & 5 & 36 & 31 & 214 & 82 & 52 & 12 & 175 & 86 & 486 & 115 \\
\hline & & 10 & 38 & 14 & 260 & 72 & 37 & 10 & 121 & 45 & 453 & 68 \\
\hline
\end{tabular}

phosphorus relative to chlorophyll may either reflect a size-dependent P/Chl ratio in the phytoplankton, or a significant $\mathrm{P}$ content in chlorophyll-free particles such as e.g. microzooplankton $>5 \mu \mathrm{m}$.

The freshwater input from the rivers at Sauda and Sand was characterized by low SRP $i<10$ to $50 \mathrm{mmal}$ $\mathrm{l}^{-1}$ ), and high nitrate $\left(4500\right.$ to $9500 \mathrm{nmol} \mathrm{l^{-1 }}$ respectively).

The phytoplankton community in the fjord system was dominated by small. flagellates, including the prymnesiophytes Chrysochromulina hirta, C. crisina, Emiliania huxleyi and Prymnesium parvum (J Egge pers. comm.)

\section{'Luxury consumption' of orthophosphate}

One hour incubation with added orthophosphate resulted in very high (230 to $442 \%$ ) increases in particulate phosphorus in the size fraction $1-0.2 \mu \mathrm{m}$ in samples from $0.5 \mathrm{~m}$ at Stn 64 (Neevoy) August 2 and 0.5 and
$2 \mathrm{~m}$ from Stn 58b (Saudafjord) on July 28 and August 2 (Fig. 5). The somewhat more moderate increase in particulate $\mathrm{P}$ in the size fraction $>1 \mu \mathrm{m}$ (52 to $182 \%$ ) may be due to a smaller storage capacity in phytoplankton. than in bacteria, but may also be interpreted as a large content of $\mathrm{P}$ in other particles in the $>1 \mu \mathrm{m}$ fraction. Assuming that around $1 / 3$ (40 out of $120 \mathrm{nmol}^{-1}$ ) of particulate- $\mathrm{P}>1 \mu \mathrm{m}$ belongs to phytoplankton in the 1 to $5 \mu \mathrm{m}$ fraction, active in orthophosphate uptake (see 'Discussion'), estimated phytoplankton 'luxury consumption' would increase to between 156 and $546 \%$. Depth profiles at Stn 53 (Hylsfjord) differed from the 2 other stations by a less pronounced response in the brackish layer, but also by signs of P-deficiency below the halocline.

\section{Uptake of ${ }^{32} \mathrm{PO}_{4}^{3-}$}

Uptake of label added as carrier-free orthophosphate was well described by the theoretically expected 


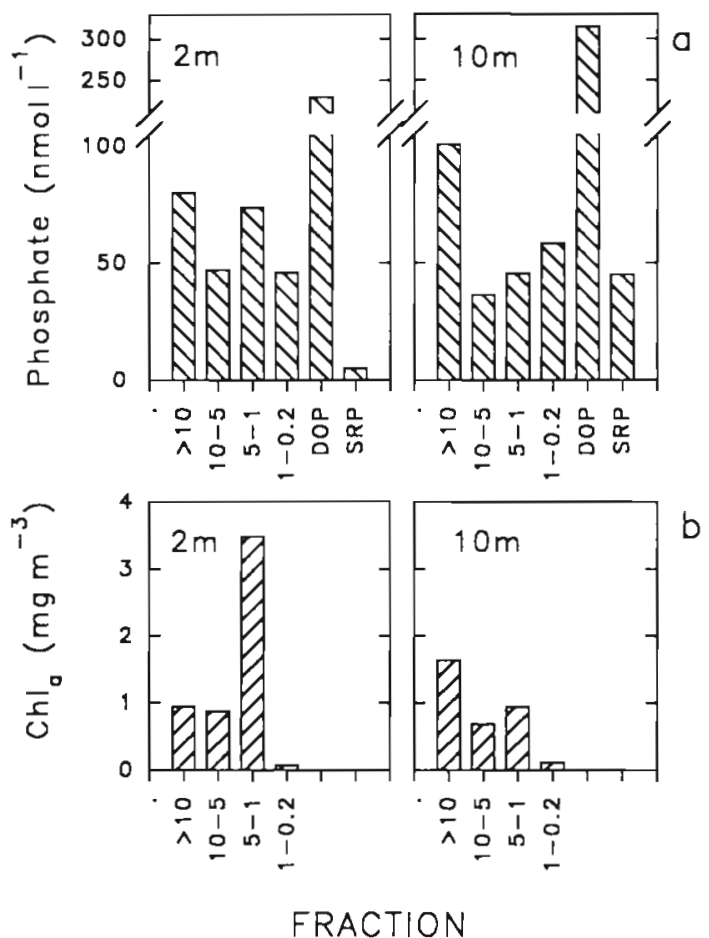

Fig. 4. Distribution of (a) phosphate between particulate size classes, DOP and SRP, and (b) chlorophyll a between particulate size classes. Samples from $2 \mathrm{~m}$ (left column) and $10 \mathrm{~m}$ (right column) Stn 53 Hylsfjord July 30

equation $r_{i}(t)=\alpha_{1}\left(1-\mathrm{e}^{-t / T_{\mathrm{PO}} 4}\right)$ (Fig. 6) with distribution of uptake between size fractions ( $\alpha_{i}$ values) as given in Table 3. The best fit was obtained assuming a loss of $10 \%$ of the label (see 'Discussion'). From these experiments, little uptake of orthophosphate seemed to occur in the size fractions $>5 \mu \mathrm{m}$ (Table 3 ), suggesting again that the particulate phosphorus found in these larger size classes (Fig. 4a) was not dominated by phytoplankton.

In isotope dilution experiments, uptake in both size fractions was usually well described by the linear model (Fig. 7, $\mathrm{R}^{2}$-values in Table 4). As was the case in the example shown in Fig. 7, uptake in the 1-0.2 $\mu \mathrm{m}$ fraction was typically characterized by low $K_{\mathrm{POA}}+S_{\mathrm{n}}$ and low $V_{\mathrm{PO} 4}^{\mathrm{m}}$ values as opposed to high values in the $>1 \mu \mathrm{m}$ fraction (Table 4 ). The 2 lines describing turnover time as function of substrate concentration therefore usually crossed as in Fig. 7. The crossing point corresponds to the substrate concentration leading to equal distribution of uptake between the 2 size fractions; uptake in the $>1 \mu \mathrm{m}$ will dominate for higher substrate concentrations, while uptake in the $1-0.2 \mu \mathrm{m}$ fraction will dominate at lower concentrations. Plotting $\%$ of uptake in size fraction $>1 \mu \mathrm{m}$ against $\log T_{\mathrm{pO} 4}$ (Fig. 8) demonstrates the covariation $\left(r^{2}=0.70\right.$ for all data, 0.84 for the brackish layer data alone) between

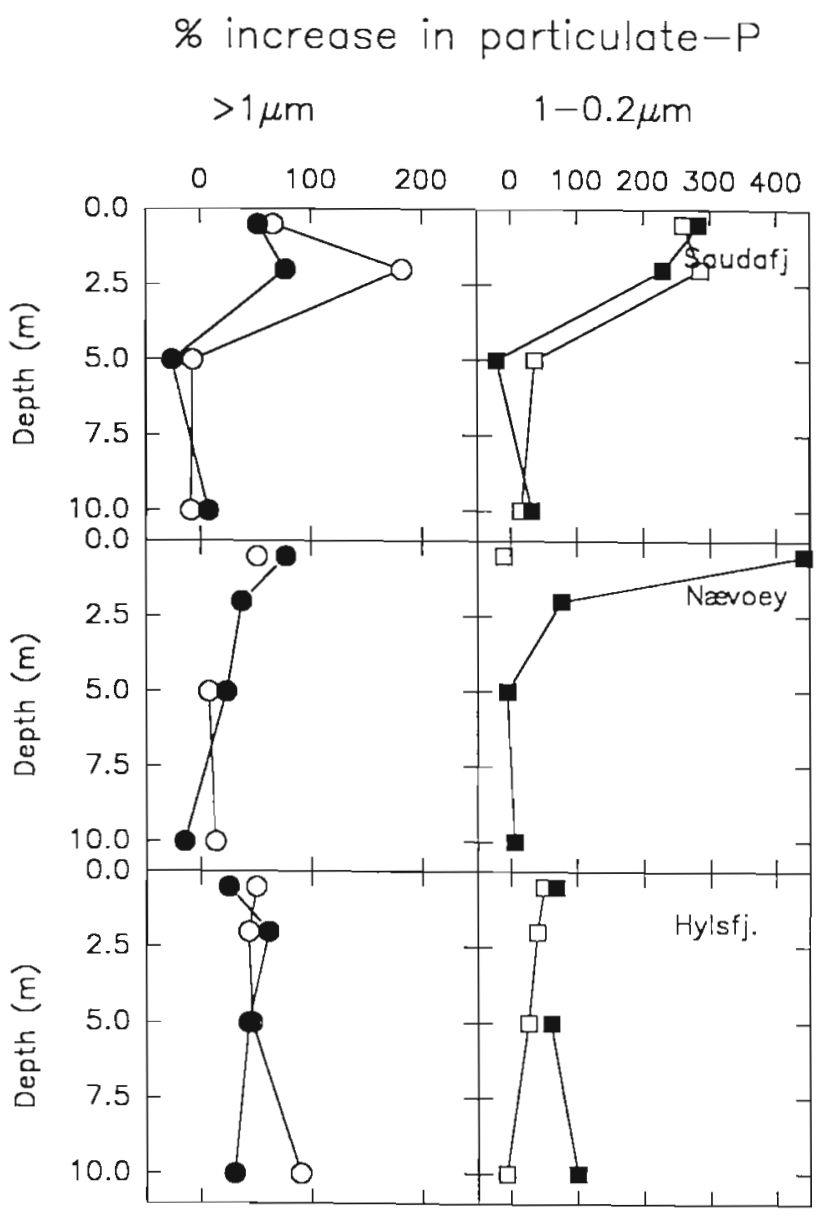

Fig. 5. 'Luxury' consumption of orthophosphate in size fractions $>1 \mu \mathrm{m}$ (left column, and $1-0.2 \mu \mathrm{m}$ (right column) at the 3 stations (upper, middle and lower panels), on July 28 (open symbols) and August 2 (closed symbols)

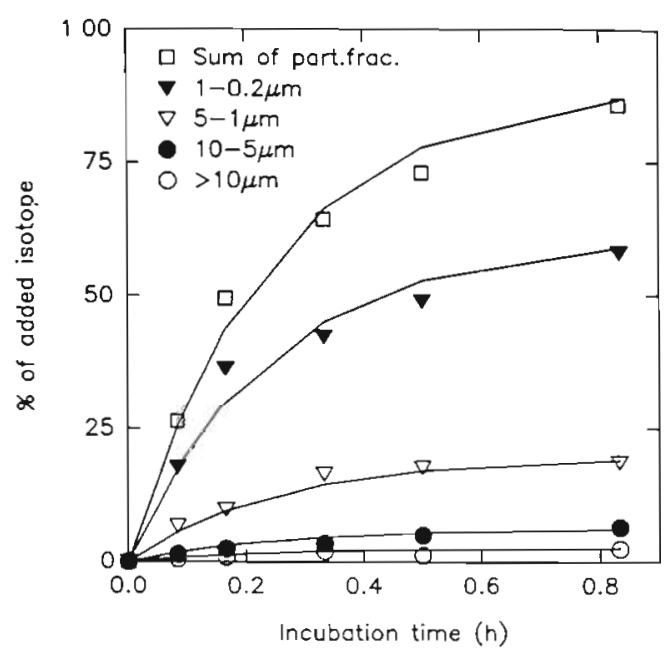

Fig. $6 .{ }^{32} \mathrm{PO}_{4}{ }^{3-}$-uptake. Transfer into different size fractions of $32 \mathrm{P}$ added as orthophosphate. Stn 53 Hylsfjord, 2 m July 30. Lines drawn assuming $1 \mathrm{st}$ order kinetics with $T_{\mathrm{POA}}=0.25 \mathrm{~h}$ and distribution of uptake between size fractions as given in Table 3 
Table 3. Distribution of orthophosphate uptake into different size fractions and as 'lost' (see text), Stn 53 July 30. Data for $2 \mathrm{~m}$ used in drawing the uptake curves of Fig. 6

\begin{tabular}{|rccccc|}
\hline & $>10 \mu \mathrm{m}$ & $10-5 \mu \mathrm{m}$ & $5-1 \mu \mathrm{m}$ & $1-0.2 \mu \mathrm{m}$ & 'Lost' \\
\hline $2 \mathrm{~m}$ & $3 \%$ & $7 \%$ & $22 \%$ & $68 \%$ & $10 \%$ \\
$10 \mathrm{~m}$ & $0 \%$ & $10 \%$ & $23 \%$ & $66 \%$ & $\mathrm{ND}$ \\
\hline
\end{tabular}

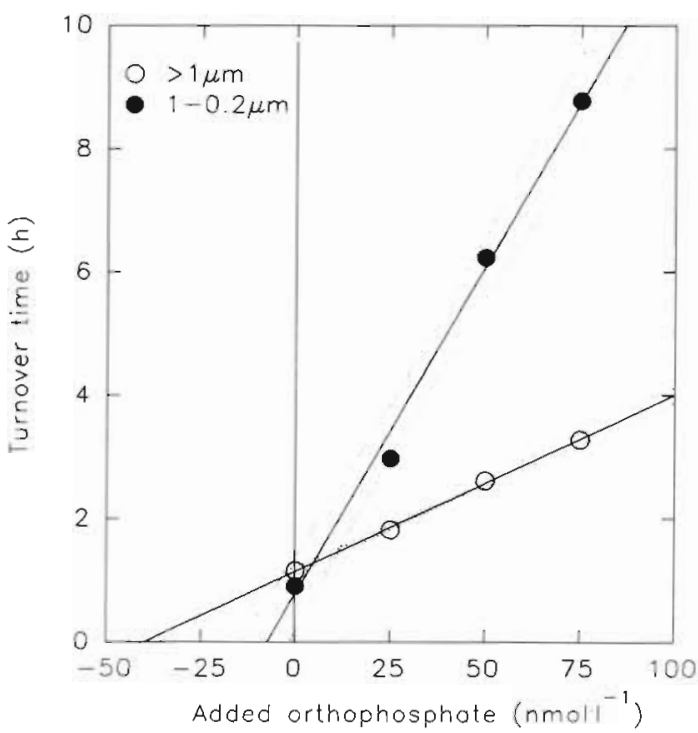

Fig. 7. ${ }^{32} \mathrm{PO}_{4}{ }^{3-}$-uptake. Concentration dependence of turnover time based on uptake in size fractions $>1 \mu \mathrm{m}$ and 1-0.2 $\mu \mathrm{m}$ respectively. Stn 5.3, 2 m. Hylsfjord August 2. Regression lines

(solid) shown with $95 \%$ confidence intervals (dotted)

these two, with the brackish layer characterized by bacteria-dominated uptake (max. $87 \%$ of total uptake) and short turnover times (min. $0.28 \mathrm{~h}$ ), and the underlying water mass by algal dominance (max. $70 \%$ ) and long turnover times (max, $63 \mathrm{~h}$ ). As for luxury consumption, there were particular characteristics with the depth profiles for distribution of uptake at Stn 64 in the Hylsfjord with a tendency towards increasing bacterial dominance with depth (Fig. 9). Below the halocline $T_{\mathrm{PO} 4}$ increased in a roughly exponential manner at all stations (Fig. 9).

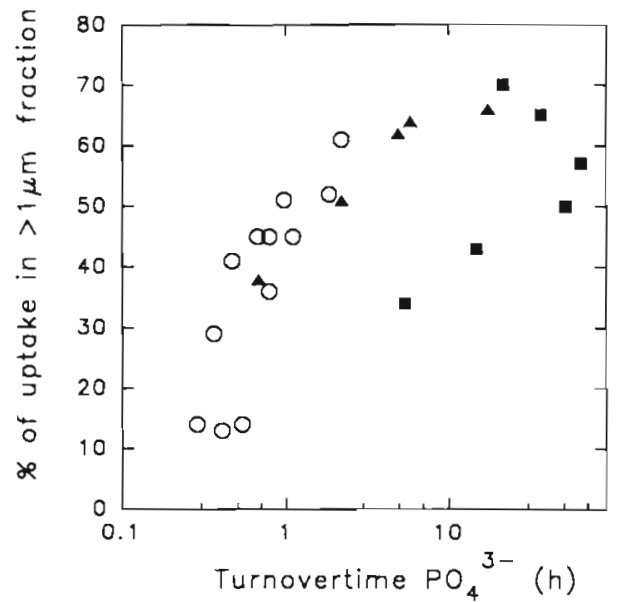

Fig. 8. ${ }^{32} \mathrm{PO}_{4}{ }^{3-}$-uptake. Scatter diagram showing the relationship between $\%$ of total uptake in the $>1 \mu \mathrm{m}$ fraction and $\log$

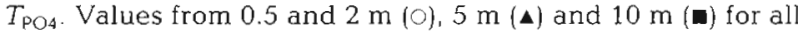
3 stations on July 27 and August 2

As a general trend, the brackish layer was characterized by high values of $V_{\mathrm{PO} 4}^{\mathrm{m}}$ and low values of $K_{\mathrm{PO} 4}+S_{\mathrm{n}}$ for both size fractions (Fig. 10), although exceptions to this pattern occurred (e.g. $K_{\mathrm{PO} 4}+S_{\mathrm{n}}$-values for the $>1 \mu \mathrm{m}$ fraction at Nævøy July 28 and in the Hylsfjord on both dates).

\section{Hydrolysis of $\gamma-\mathrm{AT}^{32} \mathrm{P}$ and $5^{\prime}$-nucleotidase activity}

In a system with short turnover times for nucleotides and $\mathrm{PO}_{4}{ }^{3-}$, the kinetics of isotope transfer from $\gamma-\mathrm{AT}^{32} \mathrm{P}$ to organisms may theoretically be fairly complex as indicated by the example in Fig. 11. The secondary transfer of label from $\mathrm{PO}_{4}{ }^{3-}$ into organisms becomes important when turnover time for free $\mathrm{PO}_{4}{ }^{3-}\left(T_{\mathrm{PO}}\right)$ and incubation time are comparable. This will lead to an underestimation of the percentage released as $\mathrm{PO}_{4}^{3-}$ (partition coefficient $f$ in Fig. 11), and an error in the estimation of the partitioning of direct uptake between algae and bacteria (partition coefficient $g$ ) dependent upon the difference between this coefficient and the partition coefficient between algae and bacteria of up-

Table 4. Uptake of ${ }^{32} \mathrm{PO}_{4}{ }^{3-}$ Pooled data for the 3 stations investigated on July 28 and August 2, grouped in samples above (0.5 and $2 \mathrm{~m})$, in $(5 \mathrm{~m})$ and below $(10 \mathrm{~m})$ the halocline

\begin{tabular}{|c|c|c|c|c|c|c|c|c|c|c|c|c|c|c|c|c|}
\hline \multirow{3}{*}{$\begin{array}{l}\text { Depth } \\
\text { (m) }\end{array}$} & \multirow{2}{*}{\multicolumn{2}{|c|}{$\begin{array}{l}T_{\mathrm{PO} 4} \\
\text { (h) }\end{array}$}} & \multirow{2}{*}{\multicolumn{2}{|c|}{$\begin{array}{c}\% \text { of uptake } \\
\text { in }>1 \mu \mathrm{m} \text { fraction }\end{array}$}} & \multicolumn{4}{|c|}{$V_{\mathrm{PO}}^{\mathrm{m}}\left(\mathrm{nmol}^{-1} \mathrm{~h}^{-1}\right)$} & \multicolumn{4}{|c|}{$K_{\mathrm{pOA}}+S_{\mathrm{n}}\left(\mathrm{nmol} \mathrm{l}^{-1}\right)$} & \multicolumn{4}{|c|}{$\mathrm{R}^{2}$} \\
\hline & & & & & \multicolumn{2}{|c|}{$>1 \mu \mathrm{m}$} & \multicolumn{2}{|c|}{$1-0.2 \mu \mathrm{m}$} & \multicolumn{2}{|c|}{$>1 \mu \mathrm{m}$} & \multicolumn{2}{|c|}{$1-0.2 \mu \mathrm{m}$} & \multicolumn{2}{|c|}{$>1 \mu \mathrm{m}$} & \multicolumn{2}{|c|}{$1-0.2 \mu \mathrm{m}$} \\
\hline & Mean & $\mathrm{SD}$ & Mean & $\mathrm{SD}$ & Mean & $S D$ & Mean & SD & Mean & $S D$ & Mean & SD & Mean & $\mathrm{SD}$ & Mean & $\mathrm{SD}$ \\
\hline $0.5 \& 2$ & 0.9 & 0.6 & $37 \%$ & $16 \%$ & 18 & 5 & 10 & 5 & 37 & 14 & 12 & 7 & 0.96 & 0.05 & 0.98 & 0.02 \\
\hline 5 & 6 & 7 & $56 \%$ & $12 \%$ & 9 & 8 & 4 & 3 & 53 & 24 & 34 & 24 & 0.94 & 0.05 & 0.95 & 0.05 \\
\hline 10 & 32 & 22 & $53 \%$ & $13 \%$ & 1.0 & 0.6 & 0.5 & 0.2 & 43 & 18 & 32 & 21 & 0.92 & 0.09 & 0.85 & 0.11 \\
\hline
\end{tabular}




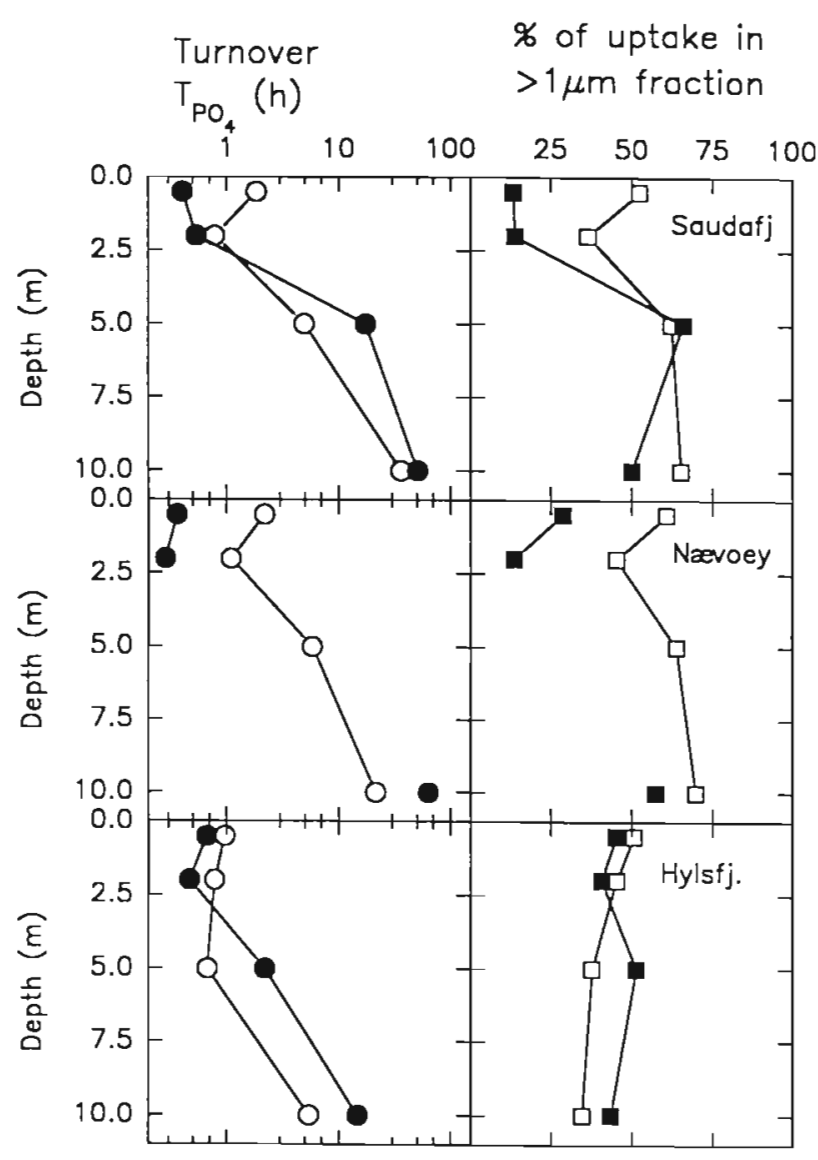

Fig. 9. ${ }^{32} \mathrm{PO}_{4}{ }^{3-}$-uptake. Depth profiles of orthophosphate turnover time $T_{\mathrm{PO} 4}$ (left column, logarithmic scale) and \% of uptake in size fraction $>1 \mu \mathrm{m}$ (right column), at the 3 stations (upper, middle and lower panels), on July 27 (open symbols) and August 2 (closed symbols)

take of free $\mathrm{PO}_{4}{ }^{3-}$ (partition coefficient $h$ ). A cold chase of unlabeled $\mathrm{PO}_{4}{ }^{3-}$ to such a system may have at least 3 different effects: (1) isotope dilution of the pool of free $\mathrm{PO}_{4}^{3-}$, (2) isotope dilution of a hypothesized pool of $\mathrm{PO}_{4}^{3-}$ in the periplasmatic space from which direct uptake occurs, and (3) inhibition of alkaline phosphatases reducing the hydrolysis rate of $\gamma-\mathrm{AT}^{32} \mathrm{P}$. In an experiment of this kind (Fig. 12), label in the $\mathrm{PO}_{4}{ }^{3-}$ pool leveled off at around $30 \mathrm{~min}$. Little effect of a cold chase was found on total hydrolysis, suggesting that ATPhydrolysis by APA was not important. Incorporation was inhibited by ca $40 \%$ and ca $70 \%$ respectively in the size fractions $>1 \mu \mathrm{m}$ and $1-0.2 \mu \mathrm{m}$ but the relative effects of isotope dilutions of types (1) and (2) above were not evaluated.

In most samples, hydrolytic activity (APA+5PNA) for $\gamma-\mathrm{AT}^{32} \mathrm{P}$ followed the linear model when turnover time was plotted against added substrate (Table 5, Fig. 13).

As for orthophosphate uptake, the estimated turnover time for nucleotides increased roughly in an exponential manner with depth below the brackish layer, from the order of $1 \mathrm{~h}$ to about $10 \mathrm{~h}$ at $10 \mathrm{~m}$ (Fig. 14). Between 44 and $95 \%$ of the hydrolyzed label was recovered as $\mathrm{PO}_{4}{ }^{3-}$ in these 30 min incubation experiments, generally with the higher values below the halocline (Fig. 14). The proportion of incorporated label taken up by the $>1 \mu \mathrm{m}$ fraction generally decreased with depth, but there was also a variation between stations with high values at Stn 58b (Saudafjord) and low at Stn 53 (Hylsfjord) (Fig. 14). When high estimates were found for $V_{5 \text { PNA }}^{\mathrm{m}} \mathrm{APA}$ or $K_{5 \mathrm{PNA}+\mathrm{APA}}+S_{n}$, these were associated with the brackish layer (Fig. 15).

In the brackish layer there was a linear relationship $\left(y=-23 \%+0.99 x, r^{2}=0.81\right)$ between \% incorporated in size fraction $>1 \mu \mathrm{m}$ when label was added as $\gamma$ $\mathrm{AT}^{32} \mathrm{P}$ and when it was added as ${ }^{32} \mathrm{PO}_{4}{ }^{3-}$, i.e. ca $23 \%$ more went into the phytoplankton fraction when $\gamma$ $\mathrm{AT}^{32} \mathrm{P}$ was the substrate (Fig. 16). For the underlying water, no similarly clear relationship was found. Characteristic for the underlying water mass was the large variations in the distribution of uptake from $\gamma$ - $\mathrm{AT}^{32} \mathrm{P}(18 \%$ to $84 \%$ in size fraction $>1 \mu \mathrm{m})$. An anticipated approach towards a 1:1 relationship due to uncoupling of hydrolysis and uptake in deeper layers with presumably higher orthophosphate concentrations was therefore not found.

Two experiments were done to estimate the association of 5PNA and APA with different size fractions and to distinguish hydrolysis of the added $\gamma-A^{32} \mathrm{P}$ due to 5PNA from the hydrolysis due to APA based on competitive inhibition of APA by addition of G6P. The hydrolytic activity (sum of APA and 5PNA) was fairly evenly distributed between the fractions $>1 \mu \mathrm{m}, 1-0.2$ $\mu \mathrm{m}$, and dissolved (Table 6). Hydrolytic activity was dominated by 5PNA, both in the water as a whole and in each fraction, a result in accordance with the conclusion reached from adding cold $\mathrm{PO}_{4}{ }^{3-}$ (Fig.12). ${ }^{32} \mathrm{PO}_{4}{ }^{3-}$ release by particulate-bound 5PNA ranged from $14 \%$ (Hylsfjord, $>1 \mu \mathrm{m}$ fraction) to $86 \%$ (Saudafjord, $>1 \mu \mathrm{m}$ fraction) of the uptake in the same fraction (calculated from the rates given in Table 7). These experiments did not provide an explanation to the shift towards uptake in the $>1 \mu \mathrm{m}$ fraction observed when label was added as $\gamma-\mathrm{AT}^{32} \mathrm{P}$ (Fig. 16, brackish layer samples). None of the enzymes were to any extreme extent associated with this size fraction (Table 6), nor were there any extreme differences between label incorporated and label released for the enzymes associated with the 2 size fractions (Table 7).

\section{Alkaline phosphatase activity (APA)}

Concentration dependence of APA alone (excluding 5PNA) was determined fluorometrically with substrate (MFP) additions in the range 25 to $100 \mathrm{nmol} \mathrm{l}^{-1}$. This 


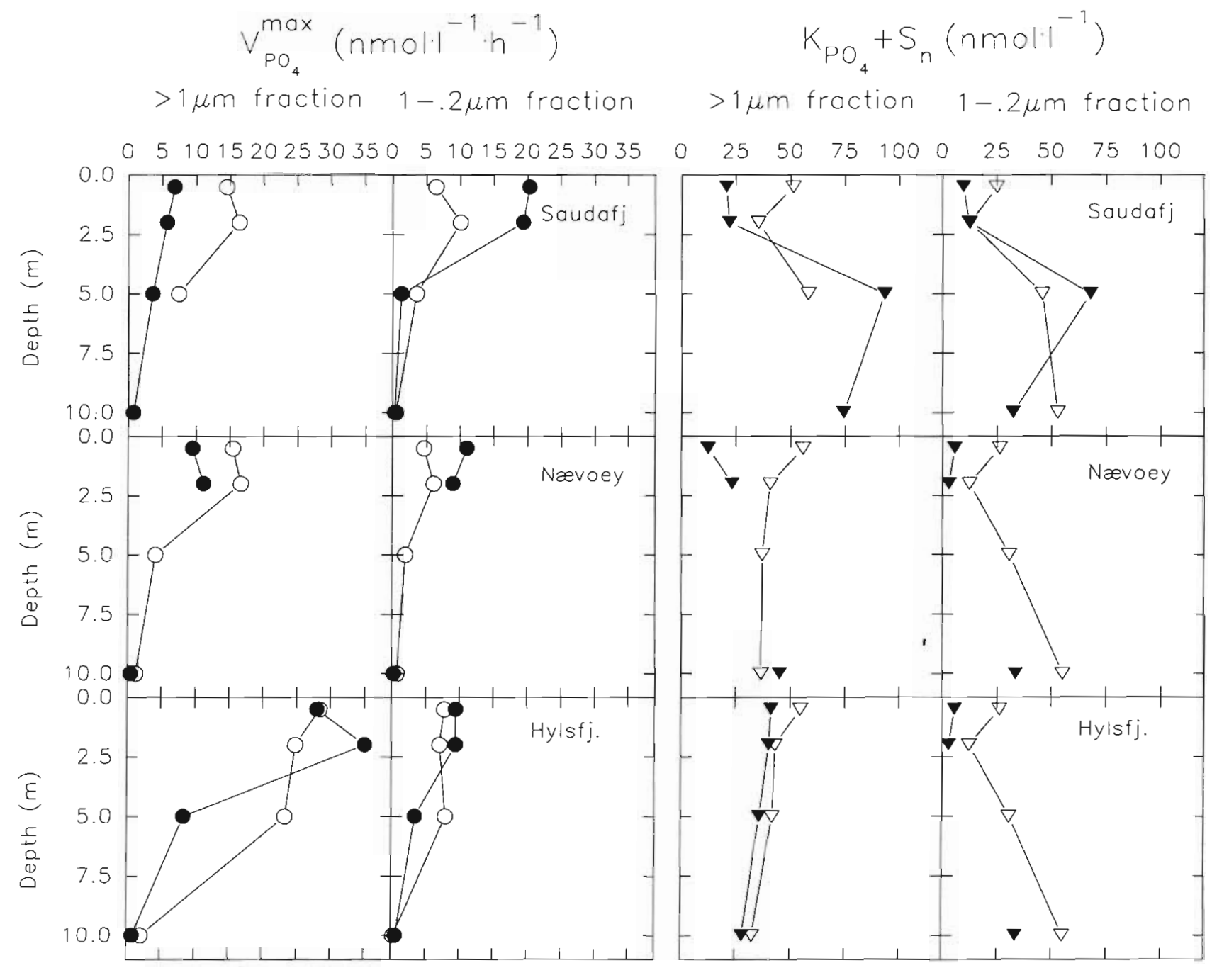

Fig. 10. ${ }^{32} \mathrm{PO}_{4}{ }^{3-}$-uptake. Depth profiles of $V_{\mathrm{PO} 4}^{\mathrm{m}}$ (1st and 2 nd columns) and $K_{\mathrm{PO} 4}+S_{\mathrm{n}}$ (3rd and 4 th columns) for orthophosphate uptake in the 2 size fractions $>1 \mu \mathrm{m}$ (1st and 3rd columns) and $1-0.2 \mu \mathrm{m}$ ( 2 nd and 4 th columns) at the 3 stations (upper, middle and lower panels) on July 27 (open symbols) and August 2 (closed symbols)

gave reasonable fit to the linear model (Fig. 17) with most $r^{2}$-values above 0.95 (Table 8).

$V_{\mathrm{APA}}^{\mathrm{m}}$ was much higher in the brackish layer than below, while the change in $K_{\mathrm{APA}}+S_{n}$ gave no clear indication of any increase in PME concentration below the halocline (Table 8, Fig. 18). For all 3 stations investigated, the depth profiles of both $V_{\mathrm{APA}_{\mathrm{A}}}^{m_{1}}$ and $K_{\mathrm{APA}}$ changed between July 28 and August 2, with a general trend towards sinking values for both (Fig, 18). The biological background for such a decrease may either be a decrease in available substrates (decrease in $S_{n}$ ), or a change in the types of alkaline phosphatases (change in $\left.K_{A P A}\right)$. The values for $K_{A P A}+S_{n}$ obtained by this fluorometric method (mean $311 \mathrm{nmol} \mathrm{l}^{-1}$ in the brackish layer) are substantially higher than the values for $K_{5 P N A+A P A}+S_{n}$ obtained using $\gamma-A T^{32} \mathrm{P}$ (mean $55 \mathrm{nmol}^{-1}$ ). This may also be explained either by an additional pool of substrates for AP (higher $S_{n}$ ) or by lower $K$-values for 5PN than for AP. The values obtained for $V_{\mathrm{APA}}^{\mathrm{m}}$ are also higher (mean 115 nmol $\mathrm{l}^{-1} \mathrm{~h}^{-1}$ in the brackish layer) than those obtained for $V_{\mathrm{APA}+5 \mathrm{PNA}}^{\mathrm{m}}$ using $\gamma-A T^{32} \mathrm{P}$ (mean $53 \mathrm{nmol}$ $\mathrm{l}^{-1} \mathrm{~h}^{-1}$ ) and therefore not really supporting a model where APA is equally active on all PME's. The shift in $K_{\mathrm{APA}}+S_{\mathrm{n}}$ when glucose-6-phosphate (G6P), ATP, or $\mathrm{PO}_{4}^{3-}$ was added to the sample was investigated on 2 occasions (Table 9). The results indicated a somewhat higher affinity for the artificial substrate than for G6P or ATP, but the differences were not statistically significant.

Estimated turnover time for PME due to APA reached a minimum of less than $1 \mathrm{~h}$ in the brackish layer (Hylsfjord August 2). As for $\mathrm{PO}_{4}{ }^{3-}$-uptake and ATP-turnover, turnover times increased with depth in 


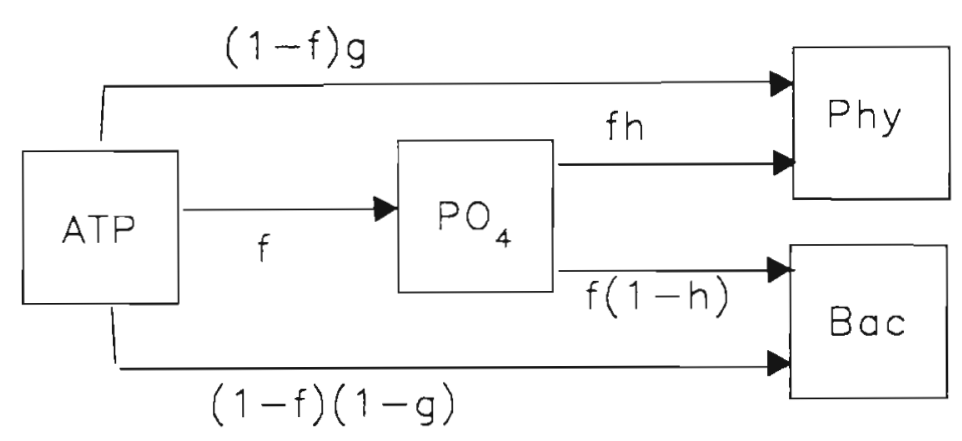

$$
\begin{aligned}
& I_{A T P}=e^{-\frac{t}{T_{A T P}}} \\
& I_{P O_{4}}=f \frac{T_{P O_{4}}}{T_{P O_{4}}-T_{A T P}}\left(e^{-\frac{t}{T_{P O_{4}}}}-e^{-\frac{t}{T_{A T P}}}\right) \\
& I_{P h y t}=g(1-f)\left(1-e^{-\frac{t}{T_{A T P}}}\right)+h f \frac{T_{P O_{4}}}{T_{P O_{4}}-T_{A T P}}\left[\left(1-e^{-\frac{t}{T_{P O_{4}}}}\right)-\frac{T_{A T P}}{T_{P O_{4}}}\left(1-e^{-\frac{t}{T_{A T P}}}\right)\right] \\
& I_{B A C t}=(1-g)(1-f)\left(1-e^{-\frac{t}{T_{A T P}}}\right)+(1-h) f \frac{T_{P O_{4}}}{T_{P O_{4}}-T_{A T P}}\left[\left(1-e^{-\frac{t}{T_{P O_{4}}}}\right)-\frac{T_{A T P}}{T_{P O_{4}}}\left(1-e^{-\frac{t}{T_{A T P}}}\right)\right]
\end{aligned}
$$

$$
T_{\text {ATP }}=1.0 h T_{P_{4}}=0.7 h \quad f=0.7 \quad g=0.2 h=0.8
$$

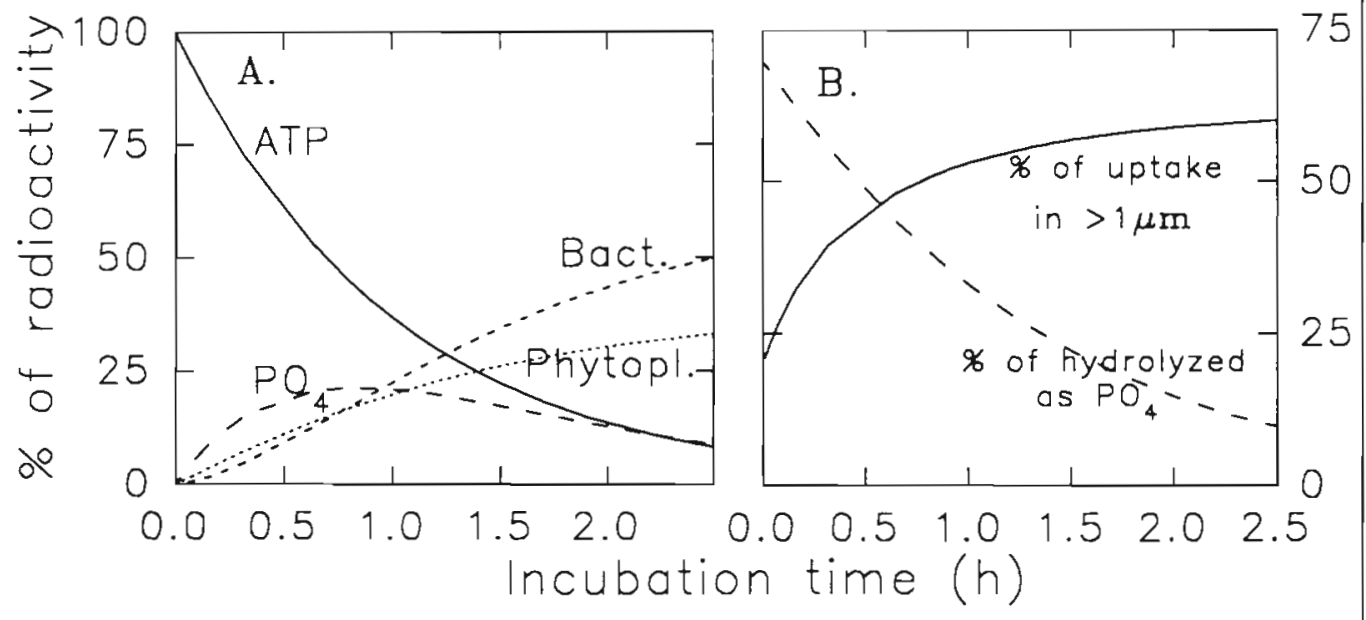

Fig. 11 Theoretical transfer of label from ATP to algae and bacteria. Based on the assumed flow diagram with partitioning coefficients $f$ for distribution between free $\mathrm{PO}_{4}{ }^{3}$ and particles, $g$ between direct uptake in algae and in bacteria, and $h$ between uptake in algae and bacteria of free $\mathrm{PO}_{4}{ }^{3-}$, the equations shown for fractions $r_{\mathrm{ATP}}, r_{\mathrm{PO}}, r_{\mathrm{Phy}}$ and $r_{\mathrm{Bact}}$ of label as ATP, as free PO${ }_{4}{ }^{3}$, and in phytoplankton and bacteria may be derived. For the parameter values given, the predicted development over time in (A) distribution of label, and $(\mathrm{B})$ in $\%$ of total hydrolysis liberated as $\mathrm{PO}_{4}{ }^{3-}$ and $\%$ of total uptake in size fraction $>1 \mu \mathrm{m}$ are shown

a roughly exponentially manner below the halocline (Fig. 18) to values around $15 \mathrm{~h}$ at $10 \mathrm{~m}$ depth.

Size fractionation of APA at 2 stations gave quite dif- ferent results (Table 10) for the $>1 \mu \mathrm{m}$ fraction with no detectable activity in this fraction at Stn 58 b (Saudafjord, 2 m August 1 ) and $29 \%$ of activity in unfraction- 


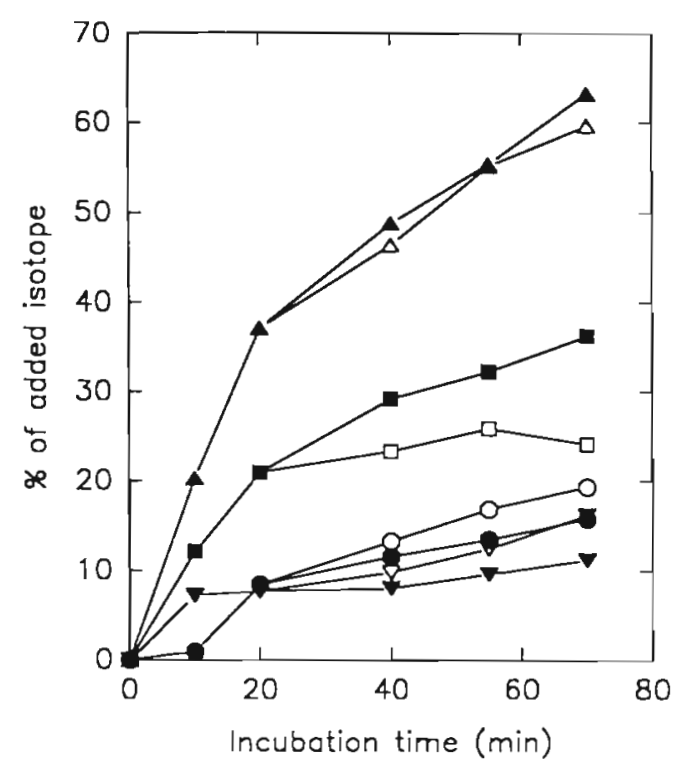

Fig. 12. Hydrolysis of $\gamma-\mathrm{AT}^{32} \mathrm{P}$. Transfer of label as function of incubation time and effect of added 'cold' $\mathrm{PO}_{4}{ }^{3-}$. Open symbols: control; closed symbols: $10 \mu \mathrm{mol} \mathrm{PO}_{4}{ }^{3-} \mathrm{1}^{-1}$ added $20 \mathrm{~min}$ after addition of $\gamma-\mathrm{AT}^{32} \mathrm{P}$. Circles: uptake in $>1 \mu \mathrm{m}$ size fraction; inverted triangles: uptake in $1-0.2 \mu \mathrm{m}$ size fraction; squares: released as $\mathrm{PO}-$; triangles: total amount hydrolyzed. Stn 53, Hylsfjorden $2 \mathrm{~m}$, July 31

ated water at Stn 53 (Hylsfjord, $2 \mathrm{~m}$ August 3). With $26 \%$ and $69 \%$ of the activity in the $1-0.2 \mu \mathrm{m}$ fraction, a high, but variable, part of the alkaline phosphatases may have bacterial origin. The high activity in the filtrate also suggests that a large fraction of the activity may be free in the water.

\section{Cold chase experiment}

The added ${ }^{32} \mathrm{PO}_{4}{ }^{3-}$ rapidly moved into the $>1 \mu \mathrm{m}$ and $1-0.2 \mu \mathrm{m}$ fractions with a strong dominance of uptake in the smaller size fraction in this sample from $2 \mathrm{~m}$ Stn 53 July 29. Following the cold chase with orthophosphate (Fig. 19b), the label slowly disappeared from the $1-0.2 \mu \mathrm{m}$ fraction at a rate of approximately $0.02 \mathrm{~h}^{-1}$, reappearing in the orthophosphate and the DOP-pools. No significant net transfer of label to any of the size fractions $>1 \mu \mathrm{m}$ could be detected. In the incubation without cold chase (Fig. 19a), label did not reappear in the orthophosphate fraction but label disappearance from the 1-0.2 $\mu \mathrm{m}$ fraction ceased after approximately $24 \mathrm{~h}$ and some label also appeared in larger size fractions.

\section{DISCUSSION}

With this fairly complex system, a feeling for the consistency of the results is best obtained by exploring the

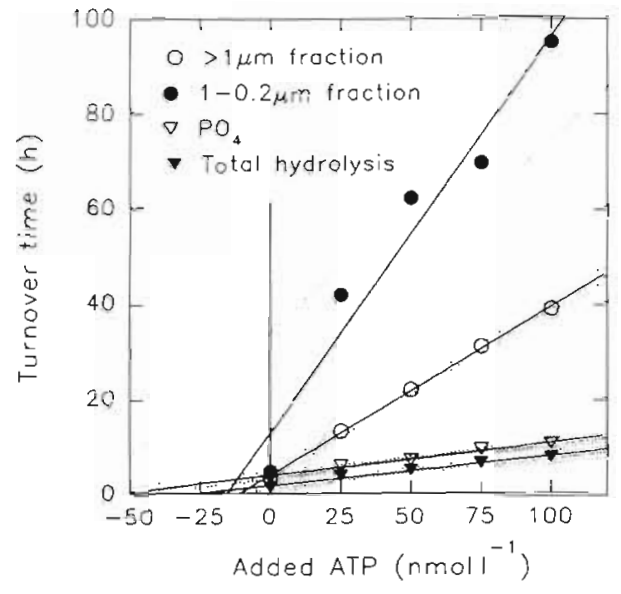

Fig. 13. Hydrolysis of $\gamma-\mathrm{AT}^{32} \mathrm{P}$. Concentration dependence of turnovertime. Stn 64 Næevøy, 2 m, July 28. Fitted regression lines (solid) shown with $95 \%$ confidence intervals (dotted)

possibilities for assembling a consistent diagram quantifying the flow of phosphorus through the microbial food web, as summarized in Fig. 20. To do this, we will assume that the P-flow was dominated by recycled rather than by imported ('new') phosphates. Input with river water was low in phosphate and transport through the halocline must also have been marginal since there was no marked concentration increase below the halocline (Table 2) and the low salinity in the brackish layer at Nævøy (ca 4 psu) implies low saltwater entrainment. Other potential sources were not quantified.

To avoid the use of SRP-values as representative of biologically available $\mathrm{PO}_{4}{ }^{3-}$, we have based the computation of rate of flow in the whole system on the disappearance rate $\left(0.02 \mathrm{~h}^{-1}\right)$ of label from the 1-0.2 $\mathrm{mm}$ fraction as obtained in the cold chase experiment. This fraction contained, as a mean, about $40 \mathrm{nmol} \mathrm{l}^{-1}$ phos. phorus. Assuming all of this to be bacterial, ca $0.8 \mathrm{nmol}$ $\mathrm{1}^{-1} \mathrm{~h}^{-1}$ would be estimated to pass through the bacteria. This is an overestimate if there is detrital or other non-bacterial phosphorus in this fraction, and it may be a slight underestimate if not all of the reabsorption of recycled phosphorus was stopped by the $\mathrm{PO}_{4}{ }^{3-}$-cold chase. Since there apparently was some uptake directly coupled to hydrolysis, uptake from free $\mathrm{PO}_{4}{ }^{3-}$ must be less than $08 \mathrm{nmol}^{-1} \mathrm{~h}^{-1}$. Using the kinetic parameters estimated for $\mathrm{PO}_{4}{ }^{3-}$-uptake in the 1-0.2 $\mu \mathrm{m}$ fraction, very low (ca $1 \mathrm{nmol}^{-1}$ ) concentrations must be assumed for the pool of free, biologically available, $\mathrm{PO}_{4}{ }^{3-}$ This is not only more than an order of magnitude below the chemically measured SRP-values (Table 2), it also means that the $K_{\mathrm{PO}_{4}}+S_{\mathrm{n}}$ values obtained from isotope dilution experiments are dominated by the $K_{\mathrm{PO} 4}$ term, and therefore unsuited for estimation of biologically available $\mathrm{PO}_{4}{ }^{3-}$ in this system. With a value 
Table 5. Hydrolysis of $\gamma-\mathrm{AT}^{32} \mathrm{P}$. Pooled data for the 3 stations investigated on July 28 and August 2 , grouped in samples above $(0.5$ and $2 \mathrm{~m})$, in $(5 \mathrm{~m})$ and below $(10 \mathrm{~m})$ the halocline

\begin{tabular}{|c|c|c|c|c|c|c|}
\hline & & Mean & SD & Min. & Max. & $\mathrm{n}$ \\
\hline \multirow{7}{*}{$0.5 \& 2 \mathrm{~m}$} & $T(\mathrm{~h})$ & 1.19 & 0.43 & 0.61 & 2.1 & 8 \\
\hline & $\%$ as uptake in $>1 \mu \mathrm{m}$ fraction & $24 \%$ & $11 \%$ & $13 \%$ & $44 \%$ & 8 \\
\hline & $\%$ as uptake in $1-0.2 \mu \mathrm{m}$ fraction & $14 \%$ & $4 \%$ & $9 \%$ & $20^{\prime \prime}$ & 8 \\
\hline & $\%$ as liberated $\mathrm{PO}_{4}{ }^{3-}$ & $60 \%$ & $9 \%$ & $44 \%$ & $70 \ldots$ & 8 \\
\hline & $V^{m}\left(\mathrm{nmol} \mathrm{l^{-1 }} \mathrm{h}^{-1}\right)$ & 53 & 33 & 16 & 97 & 8 \\
\hline & $K+S_{n}\left(\right.$ nmol l $\left.^{-1}\right)$ & 55 & 30 & 20 & 114 & 8 \\
\hline & $\mathrm{R}^{2}$ & 0.923 & 0.058 & 0.802 & 0.982 & 8 \\
\hline \multirow[t]{7}{*}{$5 \mathrm{~m}$} & $T(\mathrm{~h})$ & 2.08 & 0.49 & 1.42 & 2.8 & 6 \\
\hline & $\%$ as uptake in $>1 \mu \mathrm{m}$ fraction & $12 \%$ & $12 \%$ & $3 \%$ & $35 \%$ & 6 \\
\hline & $\%$ as uptake in $1-0.2 \mu \mathrm{m}$ fraction & $10 \%$ & $8 \%$ & $2 \%$ & $23 \%$ & 6 \\
\hline & $\%$ as liberated $\mathrm{PO}_{4}^{3-}$ & $78 \%$ & $16 \%$ & $51 \%$ & $95 \%$ & 6 \\
\hline & $V^{m}\left(\mathrm{nmol} \mathrm{l^{-1 }} \mathrm{h}^{-1}\right)$ & 24 & 14 & 6 & 45 & 6 \\
\hline & $\left.K+S_{\mathrm{n}}(\mathrm{nmol})^{-1}\right)$ & 45 & 26 & 1 & 77 & 6 \\
\hline & $\mathrm{R}^{2}$ & 0.942 & 0.029 & 0.901 & 0.972 & 6 \\
\hline \multirow[t]{7}{*}{$10 \mathrm{~m}$} & $T(\mathrm{~h})$ & 5.89 & 1.55 & 4.64 & 7.6 & 3 \\
\hline & $\%$ as uptake in $>1 \mu \mathrm{m}$ fraction & $9 \%$ & $8 \%$ & $3 \%$ & $18 \%$ & 3 \\
\hline & $\%$ as uptake in $1-0.2 \mu \mathrm{m}$ fraction & $11 \%$ & $13 \%$ & $3 \%$ & $26 \%$ & 3 \\
\hline & $\%$ as liberated $\mathrm{PO}_{4}{ }^{3-}$ & $89 \%$ & $3 \%$ & $85 \%$ & $91 \%$ & 3 \\
\hline & $V^{T n}\left(\right.$ nmol l $\left.^{-1} \mathrm{~h}^{-1}\right)$ & 9 & 5 & 5 & 15 & 3 \\
\hline & $K+S_{\mathrm{n}}\left(\mathrm{nmol} \mathrm{l}^{-1}\right)$ & 52 & 28 & 22 & 79 & 3 \\
\hline & $\mathrm{R}^{2}$ & 0.938 & 0.040 & 0.906 & 0.983 & 3 \\
\hline
\end{tabular}

chosen for free $\mathrm{PO}_{4}{ }^{3-}$, the uptake into phytoplankton is determined by the kinetic parameters of the $>1 \mu \mathrm{m}$ fraction.

To estimate the transfer of $\mathrm{PO}_{4}{ }^{3-}$ from hydrolysis of $\mathrm{PME}$, kinetic parameters for 5PN and $\mathrm{AP}$, and partitioning coefficients for the transfer of hydrolyzed $\mathrm{PO}_{4}{ }^{3-}$ directly to phytoplankton, directly to bacteria, or to the pool of dissolved $\mathrm{PO}_{4}{ }^{3-}$, are needed. For the sake of mass balance, we do not need to make any assumptions concerning the proportions of cell-bound and free enzymes or other mechanisms causing the partitioning. For 5PN, we have used the kinetic parameters obtained from $\gamma$-AT ${ }^{32} \mathrm{P}$ hydrolysis. The value used for $V_{5 \mathrm{PN}}^{\mathrm{m}}$ through this approach may be an overestimate since the observation of AP playing an insignificant role in ATP hydrolysis applied to nearly carrier-free substrate additions. A simple hypothesis describing the balance between 5PN and AP would be that 5PN are specialized enzymes with 'high affinity/low $V^{\mathrm{m}}$, and AP generalized enzymes with 'low affinity/high $V^{m}$. For AP, we have used the kinetic parameters obtained fluorometrically with MFP as substrate. With this choice, low values (ca $1 \mathrm{nmol} \mathrm{l}^{-1}$ ) must be assumed for the nucleotide concentration in order to avoid hydrolysis rates exceeding the consumption by phytoplankton and bacteria. We have assumed a PME-pool of $0.8 \mathrm{nmol} \mathrm{1}^{-1}$ dominated by nucleotides (substrates for $5 \mathrm{PN}$ and AP), but this may be replaced by somewhat higher concentrations of non-nucleotide PME's (sub- strates for AP only). With the kinetic parameters and the PME-concentration chosen, $70 \%$ of PME-hydrolysis occurs by 5PNA due to the difference in kinetics of the 2 enzymes. No entirely uniform picture for the partitioning of hydrolyzed $\mathrm{PO}_{4}{ }^{3-}$ from PME's was obtained from the experiments. In the flow diagram, a shift towards phytoplankton-dominated assimilation of label as observed for the brackish layer when label was added as $\gamma-\mathrm{AT}^{32} \mathrm{P}$ (Fig. 16) is simulated by an assumption of a $30 \%, 10 \%, 60 \%$ partitioning of 5PNA-hydrolyzed $\mathrm{PO}_{4}{ }^{3-}$ between coupled uptake in phytoplankton, in bacteria, and as released $\mathrm{PO}_{4}^{3-}$ respectively, although support for this could not be found in the data of Tables $6 \& 7$. Highly variable results were found for the distribution of APA (Tables $6 \& 10$ ). The partitioning assumed for APA in the flow diagram is $25 \%, 25 \%$, $50 \%$, corresponding roughly to the distribution of enzyme activity in Hylsfjord August 3 (Table 10). From the DOP measurements (Table 2), a PME concentration of ca $1 \mathrm{nmol}^{-1}$ would leave an average of $236 \mathrm{nmol}^{-1}$ as polymeric DOP. Interestingly, these estimates compare favorably with the calculations of Ammerman \& Azam (1991b) leading to estimated free

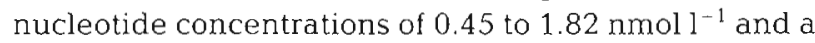
concentration of dissolved nucleic acids (DNA+RNA) of $240 \mathrm{nmol} \mathrm{l}^{-1}$. Incorporation into this flow scheme of a process with cell-bound coupling of nuclease and nucleotidase activity, as discussed by Ammerman \& Azam (1991b), would require the assumption of even 


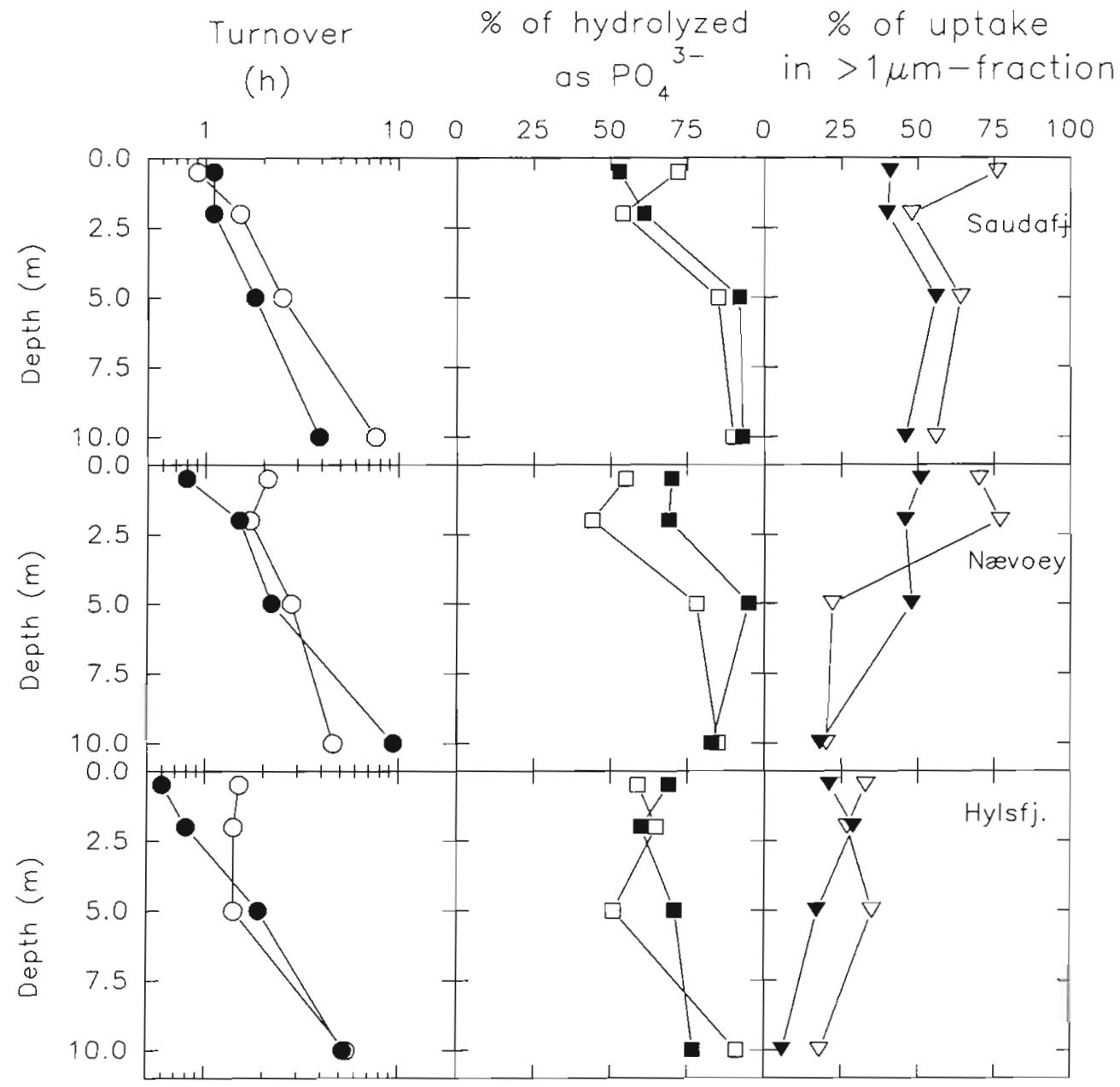

Fig. 14. Hydrolysis of $\gamma$ $A T^{32} \mathrm{P}$. Depth profiles of turnover time (left column, logaritmic scale), \% of hydrolyzed ${ }^{32} \mathrm{PO}_{4}{ }^{3-}$ released as orthophosphate (middle column), and $\%$ of ${ }^{32} \mathrm{PO}_{4}{ }^{3-}$ uptake in size fraction $>1 \mu \mathrm{m}$ (right column) at the 3 stations (upper, middle and lower line) on July 28 (open symbols), and August 2 (closed symbols) smaller concentrations of free nucleotides to avoid excessive hydrolysis

Our experimental results contain some limited information on the transport of $\mathrm{P}$ in the food chain. In the cold chase experiment (Fig. 19) we could not detect any significant transfer of the label disappearing from the $1-0.2 \mu \mathrm{m}$ fraction to larger size fractions. We have incorporated this into the flow diagram of Fig. 20 by assuming that assimilation of $\mathrm{P}$ by bacterial predators in the 1-5 $\mu \mathrm{m}$ fraction balances the loss from phytoplankton in the same fraction. Another possibility could be that bacterial predators had a very low efficiency for assimilation of $P$, or that loss of $P$ from the bacterial fraction occurred by lysis or leakage through the membrane. In the flow diagram of Fig. 20, the only function of predators in larger size classes is to release $P$ from the pools of phytoplankton and bacterial predators.

The cold chase experiment indicated that some label was released as DOP. In this experiment transfer of label from PME was probably not stopped since a cold chase with $\mathrm{PO}_{4}{ }^{3-}$ was shown to have minimal effect on hydrolysis rate of ATP (Fig. 12). Using gel filtration and ${ }^{32}$ P-labelling, Taylor \& Lean(1981) concluded that the ciliated protozoa Strombidium viride released mainly $\mathrm{PO}_{4}{ }^{3-}$. These authors, however, also only used a $\mathrm{PO}_{4}{ }^{3-}$ cold chase. Recently, Turk et al. (1992) showed that protozoan grazing on bacteria results in release of free DNA. With the limited information available, we have assumed the phosphorus released by grazing processes to be equally partitioned $(33 \%, 33 \%, 33 \%)$ between $\mathrm{PO}_{4}{ }^{3-}, \mathrm{PME}$ and polymeric DOP. Reducing the proportions of DOP would imply that lower concentrations of PME would have to be assumed to balance the fluxes, and that estimated turnovertime for the pool of polymeric DOP would increase. The quantitative consequences of the complex partitioning of $\mathrm{PO}_{4}^{3-}$ from PME-hydrolysis also become less important.

In the flow diagram suggested in Fig. 20, bacteria have a slightly dominating role over phytoplankton in the P-flow through the microbial foodweb with approximately $63 \%$ of the uptake when free orthophosphate is considered alone, and $55 \%$ when uptake coupled to cell-bound hydrolysis is included. In our experimental data, there was, however, a large degree of variation with a development in the microbial ecosystem towards strong bacterial dominance of 


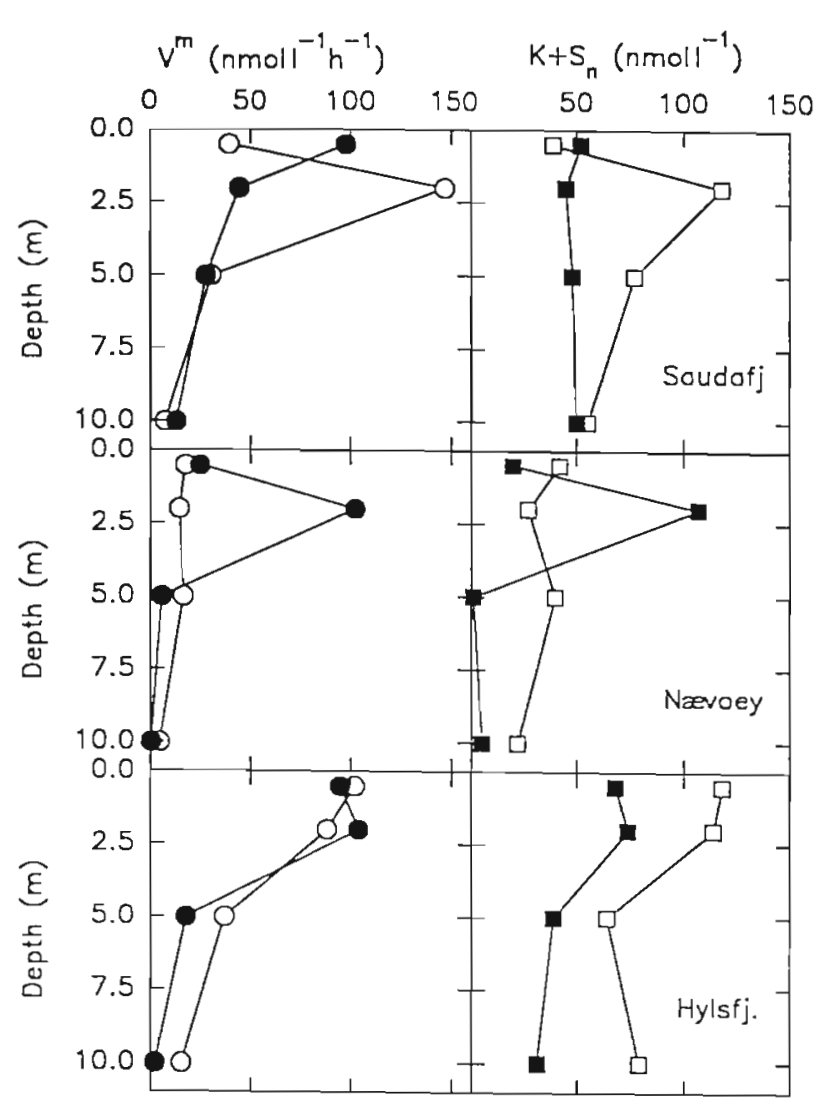

Fig. 15. Hydrolysis of $\gamma-A T^{32} \mathrm{P}$. Depth profiles of $V_{S P N A+A P A}^{m}$ (left column), and $K_{5 \mathrm{PNA}+\mathrm{APA}}+S_{\mathrm{n}}$ (right column) at the 3 stations (upper, middle and lower panels) on July 28 (open symbols) and August 2 (closed symbols)

orthophosphate uptake in the brackish layer in Saudafjord and at Nævøy between the 2 sampling dates July 28 to August 2 (Fig. 9). The large scatter in distribution of label demonstrated in Fig. 8 should also be taken as a warning not to generalize towards neither bacterial nor phytoplankton dominance of $\mathrm{P}$ -

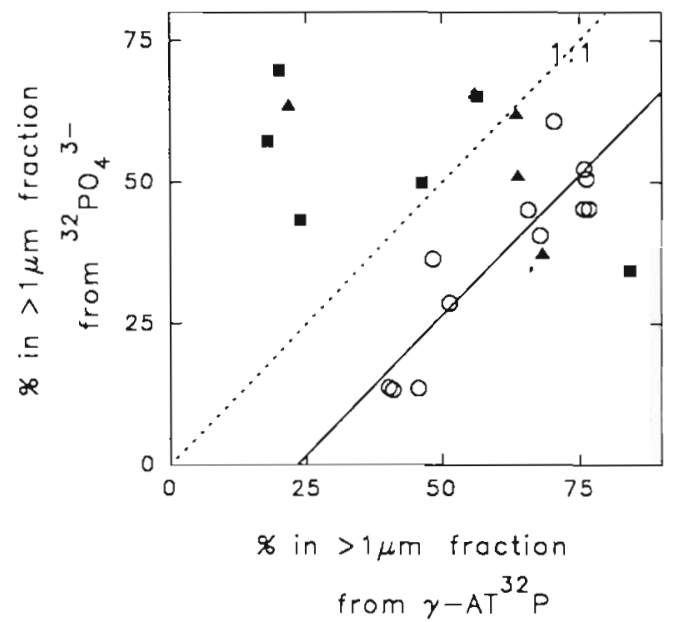

Fig. 16. Scatter diagram of partitioning of label between size fractions when added as $\gamma-\mathrm{AT}^{32} \mathrm{P}$ vs when added as ${ }^{32} \mathrm{PO}_{4}{ }^{3-}$ Regression line (solid) fitted to data from 0.5 and $2 \mathrm{~m}$ and $1: 1$ relationship (dotted). Symbols as in Fig. 8

uptake in such estuarine systems. For the biomass-P, the bacteria were estimated to contain an average of $24 \%$ of total particulate-P. Phosphate content of phytoplankton biomass can only be estimated indirectly from our data. We have used a value of $40 \mathrm{nmol} \mathrm{l}^{-1}$. This is $1 / 3$ of the mean particulate-P value in the $>1 \mu \mathrm{m}$ fraction in the brackish layer (Table 2). Since there was negligible uptake (Fig. 6), but appreciable amounts of particulate-P (Fig. 4a) in size fractions $>5 \mu \mathrm{m}$, and since the size fraction 5-1 $\mu \mathrm{m}$ would be expected to contain phosphorus in heterotrophic flagellates, this may still be an overestimate. An independent estimate may also be achieved using the chlorophyll value of $3.5 \mu \mathrm{g} \mathrm{l}^{-1}$ measured for this size fraction at $2 \mathrm{~m}$ in the Hylsfjord July 30. Using the chl:C and P:C ratios found by Tett et al. (1975), phosphorus in algal biomass would be estimated to between 45 and $49 \mathrm{nmol}$

Table 6. Distribution of 5PNA and APA based on size fractionation and on competitive inhibition of APA by addition of G6P. Sum of percentages exceeds $100 \%$ in some cases where $100 \%$ is the activity in unfractionated water

\begin{tabular}{|c|c|c|c|c|c|c|}
\hline & & \multirow{2}{*}{$\begin{array}{l}\text { As \% of activity in } \\
\text { unfractionated water } \\
\text { Hydrolytic activity } \\
\text { (APA+5PNA) }\end{array}$} & \multicolumn{2}{|c|}{$\begin{array}{l}\text { As \% of APA and 5PNA } \\
\text { in unfractionated water }\end{array}$} & \multicolumn{2}{|c|}{$\begin{array}{c}\text { As \% of hydrolytic activity } \\
\text { in each fraction }\end{array}$} \\
\hline & & & APA & 5PNA & APA & 5PNA \\
\hline Stn 53, Hylsfjord & Unfractionated & $100 \%$ & $100 \%$ & $100 \%$ & $18 \%$ & $82 \%$ \\
\hline \multirow{3}{*}{$2 \mathrm{~m}$, July 31} & $>1 \mu \mathrm{m}$ & $28 \%$ & $60 \%$ & $21 \%$ & $38 \%$ & $62 \%$ \\
\hline & $1-0.2 \mu \mathrm{m}$ & $28 \%$ & $16 \%$ & $31 \%$ & $10 \%$ & $90 \%$ \\
\hline & Dissolved & $51 \%$ & $33 \%$ & $55 \%$ & $12 \%$ & $88 \%$ \\
\hline \multirow{4}{*}{$\begin{array}{l}\text { Stn } 58 \mathrm{~b} \text {, Saudafjord } \\
2 \mathrm{~m} \text {, August } 1\end{array}$} & Unfractionated & $100 \%$ & $100 \%$ & $100 \%$ & $8 \%$ & $92 \%$ \\
\hline & $>1 \mu \mathrm{m}$ & $37 \%$ & Values too & $35 \%$ & $12 \%$ & $88 \%$ \\
\hline & $1-0.2 \mu \mathrm{m}$ & $37 \%$ & low for & $38 \%$ & $5 \%$ & $95 \%$ \\
\hline & Dissolved & $36 \%$ & reliable calculation & $39 \%$ & $0 \%$ & $100 \%$ \\
\hline
\end{tabular}


Table 7. Uptake and release of ${ }^{32} \mathrm{PO}_{4}{ }^{3-}$ hydrolyzed from $\gamma$-AT ${ }^{32} \mathrm{P}$ by 5PNA and APA estimated as remaining and removed activities respectively, following competitive inhibition by G6P addition to whole and prefractionated water samples

\begin{tabular}{|c|c|c|}
\hline & \multicolumn{2}{|c|}{$\begin{array}{l}\text { As } \% \text { of added isotope } \\
\left(h^{-1}\right)\end{array}$} \\
\hline & $\begin{array}{l}\text { Hylsfjord } \\
\text { July } 31,2 \mathrm{~m}\end{array}$ & $\begin{array}{l}\text { Saudafjord } \\
\text { Aug } 1,2 \mathrm{~m}\end{array}$ \\
\hline \multicolumn{3}{|l|}{ 5PNA } \\
\hline $5 \mathrm{PNA}$ in $>1 \mu \mathrm{m}$ fraction & $25 \%$ & $39 \%$ \\
\hline Uptake in $>1 \mu \mathrm{m}$ fraction of ${ }^{32} \mathrm{PO}_{4}$ hydrolyzed by $5 \mathrm{PNA}$ & $22 \%$ & $20 \%$ \\
\hline Difference (released as ${ }^{32} \mathrm{PO}_{4}$ ) & $3 \%$ & $19 \%$ \\
\hline 5PNA in $1-0.2 \mu \mathrm{m}$ fraction & $28 \%$ & $29 \%$ \\
\hline Uptake in $1-0.2 \mu \mathrm{m}$ fraction of ${ }^{32} \mathrm{PO}_{4}$ hydrolyzed by 5PNA & $22 \%$ & $19 \%$ \\
\hline Difference (released as ${ }^{32} \mathrm{PO}_{4}$ ) & $6 \%$ & $10 \%$ \\
\hline 5PNA in filtrate & $65 \%$ & $43 \%$ \\
\hline Release of ${ }^{32} \mathrm{PO}_{4}$ by $5 \mathrm{PNA}$ in unfractionated water & $77 \%$ & $71 \%$ \\
\hline Difference (received from particle-bound 5PNA) & $12 \%$ & $28 \%$ \\
\hline \multicolumn{3}{|l|}{ APA } \\
\hline $\mathrm{APA}$ in $>1 \mu \mathrm{m}$ fraction & $16 \%$ & $5 \%$ \\
\hline Uptake in $>1 \mu \mathrm{m}$ fraction of ${ }^{32} \mathrm{PO}_{4}$ hydrolyzed by APA & $5 \%$ & $3 \%$ \\
\hline Difference (released as ${ }^{32} \mathrm{PO}_{4}$ ) & $11 \%$ & $3 \%$ \\
\hline APA in $1-0.2 \mu \mathrm{m}$ fraction & $2 \%$ & $4 \%$ \\
\hline Uptake in $1-0.2 \mu \mathrm{m}$ fraction of ${ }^{32} \mathrm{PO}_{4}$ hydrolyzed by APA & $8 \%$ & $7 \%$ \\
\hline Difference (released as ${ }^{32} \mathrm{PO}_{4}$ ) & $-7 \%$ & $-3 \%$ \\
\hline APA in filtrate & $9 \%$ & $0 \%$ \\
\hline Release of ${ }^{32} \mathrm{PO}_{4}$ by APA in unfractionated water & $13 \%$ & $0 \%$ \\
\hline Difference (received from particle-bound APA) & $4 \%$ & $0 \%$ \\
\hline
\end{tabular}

$1^{-1}$. Combination of the flow rate estimates with such an estimate of phytoplankton-P in the size class $5-1 \mu \mathrm{m}$ results in a turnover time of about $60 \mathrm{~h}$ for the phytoplankton, as compared to about $50 \mathrm{~h}$ for bacteria obtained from the cold chase experiment. In limnetic systems, a role of bacteria in phosphate uptake more dominant than suggested in our averaged flow diagram has been suggested by several authors (Currie \&

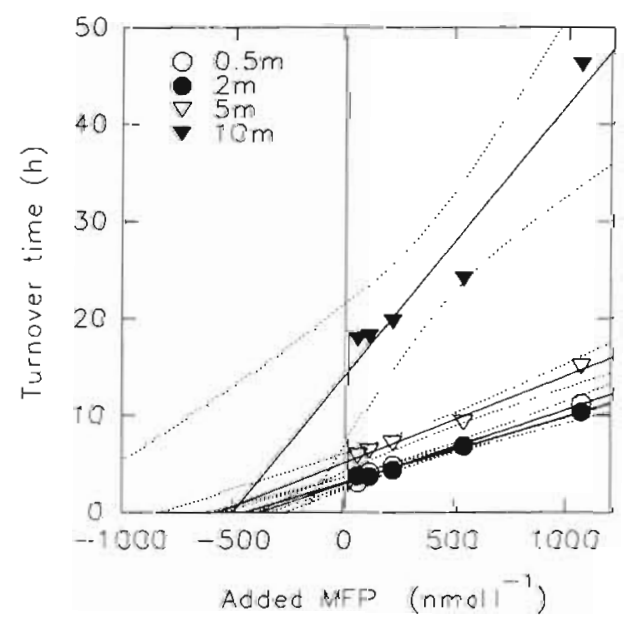

Fig. 17. MFP-hydrolysis. Concentration dependence of turnover time in samples from 4 depths. Stn 64 Nævøy, July 28. Fitted reggression lines (solid) with $95 \%$ confidence intervals (dotted)
Kalff 1984, Vadstein et al. 1988, Güde 1990, Jürgens \& Güde 1990).

The flow diagram of Fig. 20 does not contain an exchange of orthophosphate with any pool of inorganic complexes or other forms of biologically unavailable phosphates. In the experiment shown in Fig. 6, only $10 \%$ of the added label could not be accounted for as uptake into particulate fractions. This loss may either be a natural process converting orthophosphate to dissolved, but biologically unavailable forms such as adsorption to humic substances, complexation with $\mathrm{Fe}$ or other chemical processes (Cembella et al. 1984b, Froelich, 1988, Fox, 1989, DeHaan \& Salonen, 1990), or an artifact due to breakage of cells on the filters so that $10 \%$ of the or thophosphate taken up was lost to the filtrate.

There are 2 complementary, but fundamentally different, aspects related to any budget consideration in ecological food webs: (1) the quantification of pools and fluxes as discussed above, and (2) the qualitative understanding of the underlying mechanisms regulating the magnitude of these fluxes and pool sizes under various environmental conditions. Focusing on the competition aspect, the control on short and long time scales of the partitioning of phosphate uptake between algae and bacteria would be expected to be controlled by a multitude of factors influencing uptake and biomass. On the short term, the differences in uptake ki- 
Table 8. Kinetic parameters and $\mathrm{R}^{2}$-values for APA. Pooled results for samples from Stns $53,58 \mathrm{~b}$, and 64 on July 28 and August 2 taken in the brackish layer $(0.5$ and $2 \mathrm{~m})$, and in $(5 \mathrm{~m})$, and below $(10 \mathrm{~m})$ the halocline

\begin{tabular}{|c|c|c|c|c|c|c|}
\hline \multicolumn{2}{|c|}{ APA } & Mean & SD & Min. & Max. & $\mathrm{n}$ \\
\hline \multirow[t]{4}{*}{$0.5 \& 2 \mathrm{~m}$} & $V_{A P A}^{m}$ & 115 & 32 & 74 & 165 & 12 \\
\hline & $K_{\mathrm{APA}^{2}}+S_{n}$ & 311 & 167 & 95 & 687 & 12 \\
\hline & $T_{\mathrm{APA}}$ & 2.7 & 0.9 & 0.8 & 4.2 & 12 \\
\hline & $\mathrm{R}^{2}$ & 0.968 & 0.033 & 0.892 & 0.998 & 12 \\
\hline \multirow[t]{4}{*}{$5 \mathrm{~m}$} & $V^{\mathrm{m}}{ }_{\mathrm{APA}}$ & 98 & 61 & 32 & 171 & 6 \\
\hline & $K_{\mathrm{APA}}+S_{n}$ & 367 & 147 & 167 & 549 & 6 \\
\hline & $T_{\mathrm{APA}}$ & 4.8 & 2.7 & 2.5 & 8.5 & 6 \\
\hline & $\mathrm{R}^{2}$ & 0.959 & 0.043 & 0.860 & 0.998 & 6 \\
\hline \multirow[t]{4}{*}{$10 \mathrm{~m}$} & $V_{\mathrm{APA}}^{\mathrm{m}}$ & 24 & 18 & 6 & 54 & 6 \\
\hline & $K_{\mathrm{APA}}+S_{\mathrm{n}}$ & 382 & 132 & 161 & 502 & 6 \\
\hline & $T_{\mathrm{APA}}$ & 22 & 14 & 9 & 48 & 6 \\
\hline & $\mathrm{R}^{2}$ & 0.942 & 0.043 & 0.860 & 0.983 & 6 \\
\hline
\end{tabular}

must be crucial. Interacting with these will be factors such as amplitude and frequency of fluctuations in concentration of substrates and the supply of energy to the 2 populations through light and organic bacterial substrates.

From the luxury-consumption experiments, both populations were estimated to have the ability to increase their Pcontent by a factor of 4 to 5, i.e. maximum cell quota is at least 5 times minimum cell quota. The difficulty in determining the phytoplankton cell quota made it difficult to establish netics and storage capabilities would be decisive; on longer time scales, differences in biomass determining factors such as growth rates and biomass removing processes including predation, lysis or sedimentation, any difference between the 2 populations with respect to this. For uptake of orthophosphate, the phytoplankton population was estimated to be characterized by high $V^{m}$ and high $K$ values compared to bacteria.
Fig. 18. MFP-hydrolysis. Depth profiles of $V_{A P A}^{m}$ (left column), $K_{\mathrm{APA}}+S_{\mathrm{n}}$ (middle column), and turnover time $T_{\text {APA }}$ (right column). Values for the 3 stations (upper, middle and lower panels) on July 28 (open symbols) and August 2 (closed symbols)

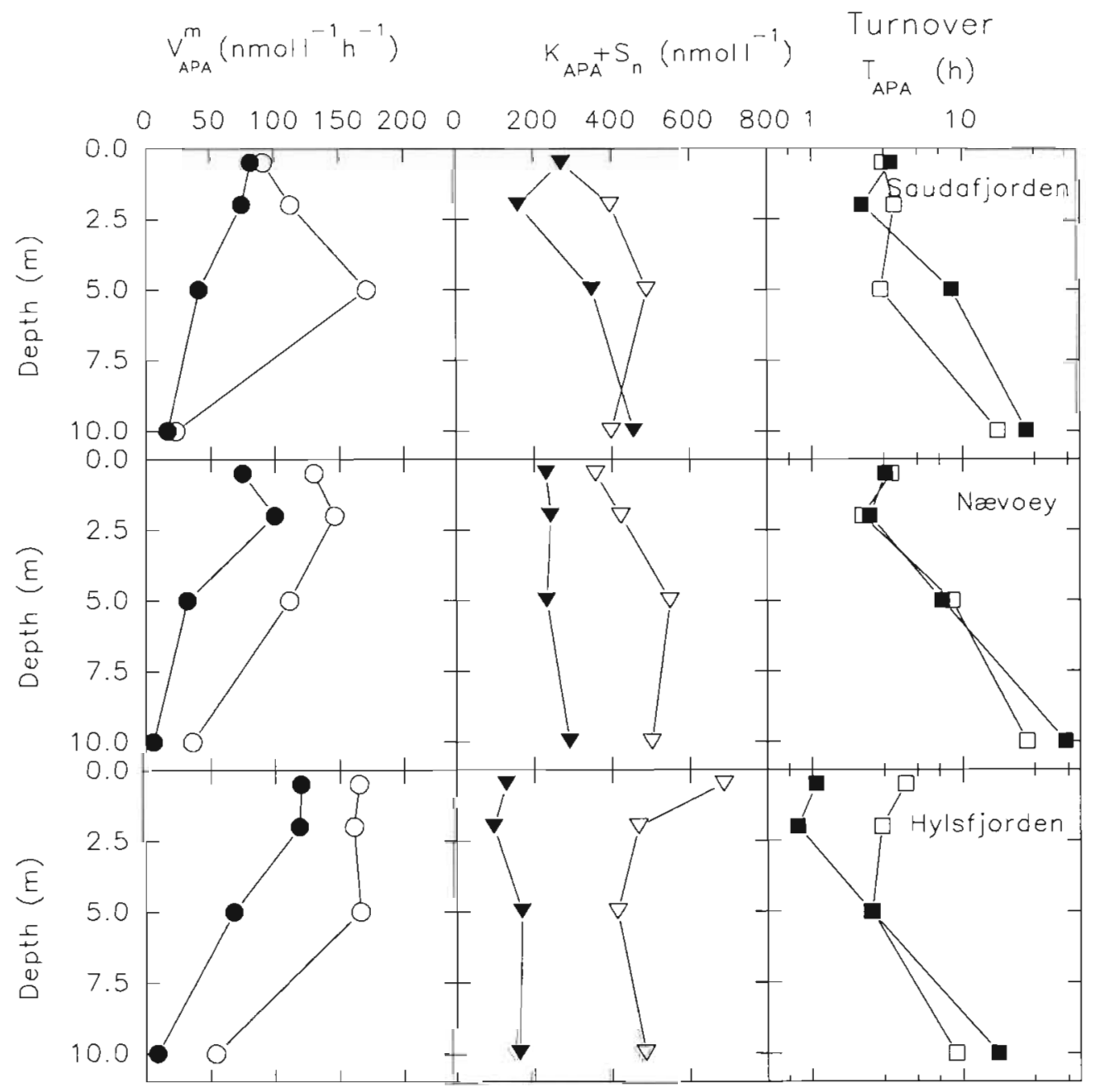


Table 9. Relative increase in $K_{\mathrm{APA}}+S_{\mathrm{n}}$ after addition of $\mathrm{PO}_{4}{ }^{3-}$. ATP and G6P. Values $=1$ would correspond to an increase equal to the added concentration of competitive inhibitor

\begin{tabular}{|ccccccc|}
\hline Addition & \multicolumn{2}{c}{$\begin{array}{c}\text { Hylsfjord } \\
\text { July } 31,2 \mathrm{~m}\end{array}$} & \multicolumn{2}{c}{$\begin{array}{c}\text { Saudafjord } \\
\text { August } 1,2 \mathrm{~m}\end{array}$} & Mean & SD \\
& $250 \mathrm{nM}$ & $500 \mathrm{nM}$ & $250 \mathrm{nM}$ & $500 \mathrm{nM}$ & & \\
\hline $\mathrm{PO}_{4}$ & 0.96 & 0.54 & 1.34 & 0.72 & 0.89 & 0.35 \\
$\mathrm{ATP}$ & 1.14 & 0.52 & 0.02 & 0.30 & 0.49 & 0.47 \\
$\mathrm{G} 6 \mathrm{P}$ & 1.70 & 0.92 & 0.24 & 0.33 & 0.80 & 0.67 \\
\hline
\end{tabular}

tion between turnover time and phytoplankton dominance of $\mathrm{PO}_{4}^{3-}$-uptake (Fig. 8). For the outcome of longterm competition at constantly low orthophosphate concentrations, the specific affinity $V^{\mathrm{m}} / K \cdot \mathrm{PP}$ is a critical parameter. With the values used in the averaged flow diagram of Fig. 20, the bacteria will have the advantage of a higher $\left(0.023 \mathrm{lnmol}^{-1} \mathrm{~h}^{-1}\right)$ specific affinity than algae $(0.013 \quad l$ $\mathrm{nmol}^{-1} \mathrm{~h}^{-1}$ ), while algae will have a

Table 10. Distribution of alkaline phosphatase activity based on MFP-hydrolysis in prefractionated samples. Results given as $\%$ of activity in unfractionated water

\begin{tabular}{|ccc|}
\hline & $\begin{array}{c}\text { Hylsfjord } \\
2 \mathrm{~m}, \text { Aug } 3\end{array}$ & $\begin{array}{c}\text { Saudafjord } \\
2 \mathrm{~m} \text {, Aug 1 }\end{array}$ \\
\hline$>1 \mu \mathrm{m}$ & $29 \%$ & $-5 \%$ \\
$1-0.2 \mu \mathrm{m}$ & $26 \%$ & $69 \%$ \\
Dissolved & $52 \%$ & $33 \%$ \\
Sum & $108 \%$ & $97 \%$ \\
\hline
\end{tabular}

Increasing levels of orthophosphate would therefore shift the uptake towards more phytoplankton dominance of the orthophosphate uptake as observed by others (Suttle et al. 1990, Cotner \& Wetzel 1992) and supported in this investigation by the positive correla-

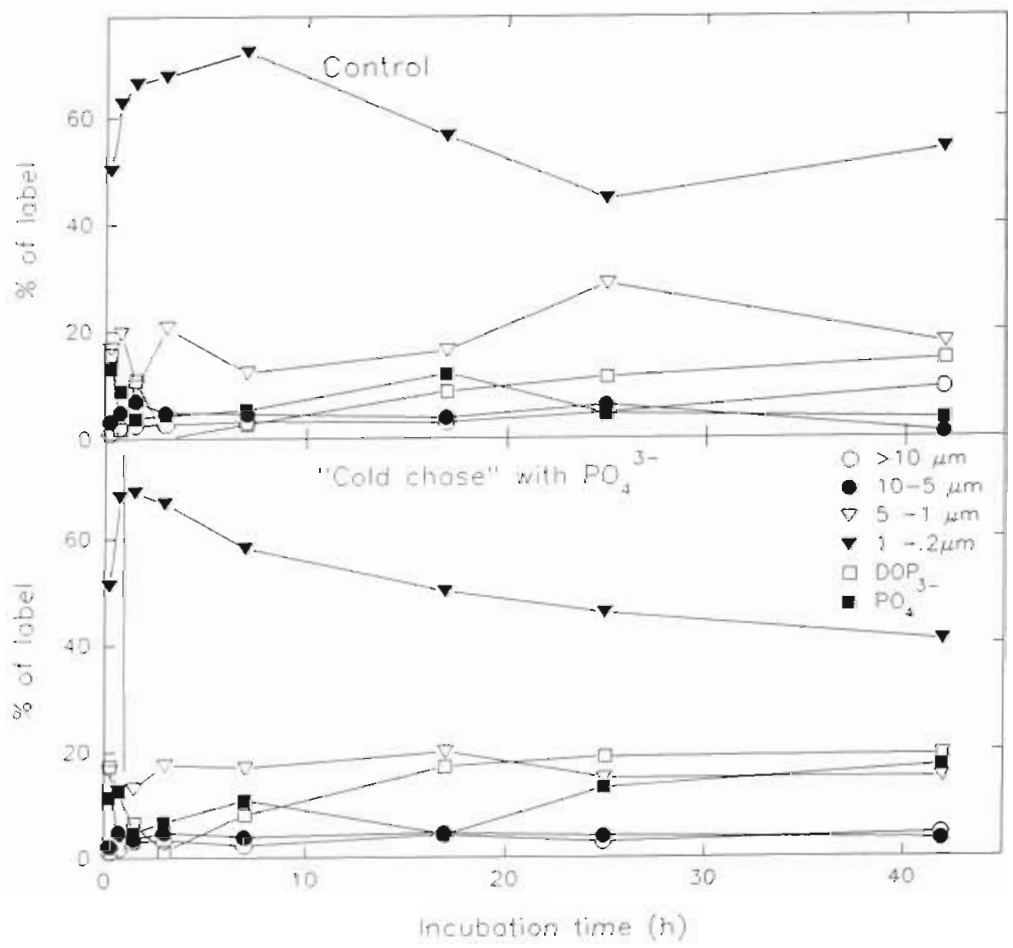

Fig. 19. Distribution of label in different fractions as function of incubation time in bottles without (a) and with (b) an orthophosphate 'cold chase' added $1.5 \mathrm{~h}$ after the addition of ${ }^{32} \mathrm{PO}_{4}$ higher maximum specific uptake rate $\left(V^{\mathrm{m}} / \mathrm{PP}\right)\left(0.5 \mathrm{~h}^{-1}\right)$ than bacteria $\left(0.25 \mathrm{~h}^{-1}\right)$. Our results do not allow a precise distinction between the populations for these parameters, again mainly because of the difficulties involved in precise determination of phytoplankton biomass-P. The qualitative conclusion that bacteria are superior competitors at constantly low concentrations, phytoplankton at high, is however in agreement with the results of Rothhaupt \& Güde (1992). The conclusion of bacterial superiority in affinity for or thophosphate is also in accordance with the results of Vadstein \& Olsen (1989), but these authors concluded that maximum P-specific uptake rates for algae and bacteria were comparable. For unknown reasons, these maximum specific uptake rates estimated from isotope dilution curves based on $15 \mathrm{~min}$ incubation are low when compared to the estimated ability of both algae and bacteria to increase their P-content with a factor of up to 5 during the $1 \mathrm{~h}$ incubations for 'luxury consumption' (Fig. 5). The existence of different uptake systems at high and low concentrations (Rosenberg et al. 1977) may be a possible explanation to this. Due to the potential decrease in uptake rate as phosphate is stored intracellularly during incubation with added orthophosphate, one would rather expect the combination of comparatively long incubation time and high addition of added orthophosphate used in the 'luxury consumption' experiments to lead to underestimation of initial uptake rates which may be very rapid in both algae (Parslow et al. 1984) and in bacteria (Nissen et al. 1987). At the 2 stations where P-deficiency in the brackish layer seemed particularly prominent (53 and 58b), $\mathrm{PO}_{4}^{3-}$-uptake was dominated by bacteria in the upper, high light intensity, part of the water column, while phytoplankton dominated the uptake in deeper and darker parts (Fig. 9), demonstrating that, within the euphotic zone, the light 


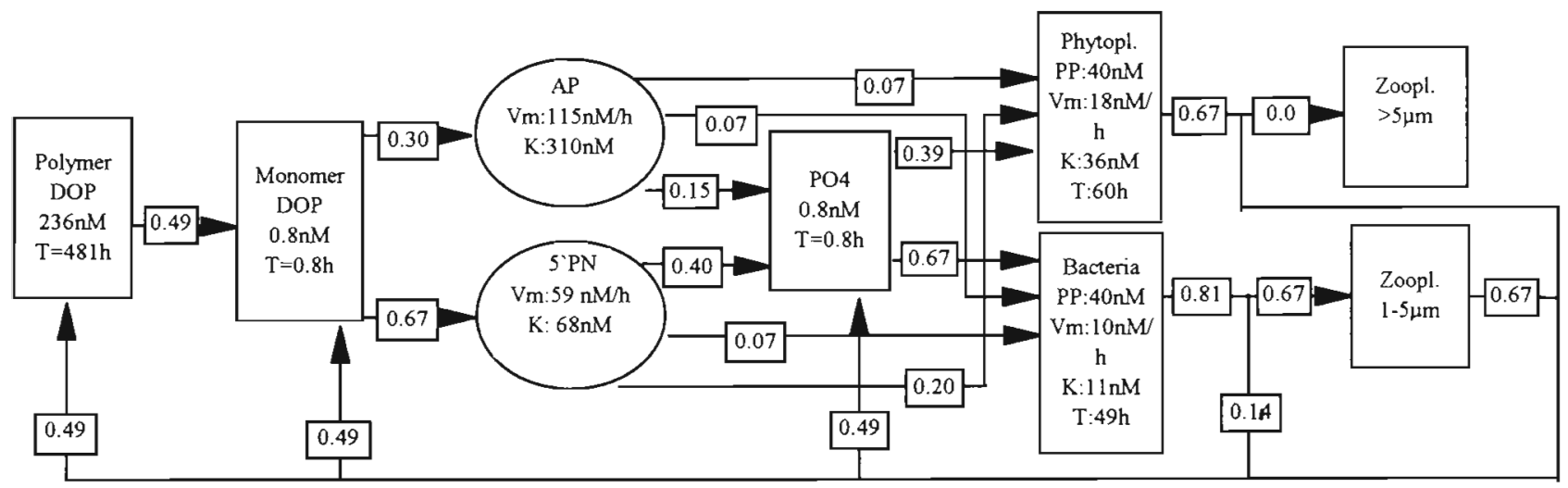

Fig. 20. Suggested 'averaged' flow diagram for the P-cycle in the brackish layer. For underlying assumptions and discussion, see text. All rates in nmol $\mathrm{l}^{-1} \mathrm{~h}^{-1}$, all compartment sizes in $\mathrm{nmol}^{-1}$, and all turnover times in hours

level is not a key factor in determining the phytoplankton/bacteria competition. The source of organic carbon driving the bacterial uptake in this system was not investigated. The combined commensalism- competition caused by algal production of organic substrates for growth of the P-competing bacteria may, however, explain a shift towards bacterial dominance with increasing limitation (Bratbak \& Thingstad 1985) as observed here.

A different approach to the budget calculations could have been taken by assuming that the measured values of SRP correctly represents biologically available orthophosphate. Using the mean SRP value of $18 \mathrm{nmol}^{-1}$ for the brackish layer, the resulting rates would be 25 times larger than those estimated in Fig. 20. This is also inconsistent with the estimated $K+S_{n}$ values for bacterial orthophosphate uptake which averaged $12 \mathrm{nmol} \mathrm{l}^{-1}$ in the brackish layer, although this discrepancy may possibly be attributed to a combination of very small $K$-values for bacterial uptake in combination with the large standard errors in estimation of $K+S_{n}$. An overestimation of biologically available orthophosphate by chemical methods may potentially be caused either by measurement of biologically unavailable complexes (De Haan \& Salonen 1990, Fox 1989, Froelich 1988) or by hydrolysis of unstable DOP-substances caused by the chemicals added for SRP determination (discussion in Karl \& Tien 1992 and references therein). If our conclusion that the $K+S_{\mathrm{n}}$ values obtained for the bacterial size fraction in isotope dilution experiments contains a halfsaturation constant of ca $11 \mathrm{nmol}^{-1}$, estimation of biologically available orthophosphate directly from isotope dilution experiments would have a lower limit of the same order of magnitude due to the required precision in the data and the present lack of knowledge of the value of $K$ for orthophosphate uptake by natural bacterial populations.

A complication of the competition situation may occur if mixotrophy is a significant process of the phytoplankton population (Estep et al. 1986). Even if phagotrophy should not be an important P-source (Caron et al. 1990) for the mixotrophic phytoplankton, such a process might have a strong regulatory effect on the microbial ecosystem caused by removal of the bacterial competitor. In the budget presented here, a maximum estimate of algal P-uptake by phagotrophy may be obtained by assuming that the phosphate flow from bacteria to $1-5 \mu \mathrm{m}$ zooplankton is caused by mixotrophic organisms alone. This would give a phagotrophic input of $0.67 \mathrm{nmol} \mathrm{l}^{-1} \mathrm{~h}^{-1}$, corresponding to $50 \%$ of phytoplankton P-consumption. With an unchanged value for algal biomass-P, this would lower the estimated turnovertime for algae to $30 \mathrm{~h}$.

The relatively low estimate of release of bacterial phosphate from the bacterial size fraction $\left(2 \% \mathrm{~h}^{-1}\right)$ is difficult to reconcile with recent work from another area suggesting high rates of viral lysis of bacteria (Bratbak et al. 1992). Unless viruses and/or DOP released during lysis adsorb strongly to the $0.2 \mu \mathrm{m}$ polycarbonate filters, a high rate of viral lysis of bacteria would be expected to induce rapid loss of label from the $1-0.2 \mu \mathrm{m}$ fraction.

Based on (1) the high nitrate combined with low phosphate concentrations, (2) a significant luxury consumption of orthophosphate, (3) high levels of alkaline phosphatase, as well as (4) short turnover time combined with low estimates for concentrations of orthophosphate and PME, both phytoplankton and bacteria appears to experience a strong P-deficit in the brackish layer of this fjord system. The situation in oligotrophic waters whith phytoplankton growing at near maximum growth rates with few signs of physiological nutrient limitation (Goldman et al. 1979), does not seem to be parallelled in these fjord systems. Occurrences of phytoplankton P-limitation in the top layer of other Norwegian fjords has been previously described (Sakshaug et al. 1983, Paasche \& Erga 1988). In the present 
case, physiological P- deficit apparently occurs despite the existence of relatively high concentrations of DOP. In the framework of the flow diagram in Fig. 20, this would be explained by the common assumption (Cembella et al. 1984a) that the pool of DOP mainly consists of polymers and a limiting rate of hydrolysis of these into PME's, restricting the rate at which substrates are made available to $5 \mathrm{PN}$ and AP. As a result, a long turnover time (ca $500 \mathrm{~h}$ ) is estimated for the pool of polymeric DOP in Fig. 20, but the value of this depends on the partition coefficients assumed for release of DOP, PME's and $\mathrm{PO}_{4}{ }^{3-}$ from zooplankton.

Aure \& Rey(1992) have presented a ritrogen budget for this fjord system in a period when fresh water release from the hydroelectric power plant in Hylsfjord produced an upwelling by entrainment of saline water. In their study a reasonable balance was found between estimates of primary production and 'new' nitrogen consumption, while there was a major deficit in the Pbudget based on the assumption of a Redfield ratio in biological consumption of $\mathrm{N}$ and P. From the results presented here, there are 2 (not mutually exclusive) explanations to the apparent P-deficit in the budgets of Aure \& Rey (1992): either there is a net consumption in the fjord from the comparatively large reservoir of PDOP, or the biomass formed has a P-content below Redfield's ratio. The first theory should presumably predict high DOP levels in incoming coastal water below the halocline at Nævøy, and low levels in the outflowing brackish layer. No support for such a mechanism was found in the depth distribution of PDOP at Nævøy, although concentrations of DOP where generally higher here than at the inner stations. The other theory of a skewed N:P-ratio was indirectly supported by our findings of a large ability for rapid uptake of added orthophosphate.

The high maximum rates and storage capacities as compared to the estimated flow rates through the system would make this system very sensitive to concentration fluctuations in time and space. Averaged flow diagrams as the one in Fig. 20 may therefore conceal important mechanisms related to inhomogenities on the microbial scale (Azam \& Smith 1991, Rothhaupt \& Güde 1992). Generalizations of the averaged flow diagram of Fig. 20 should only be done with great caution, both for this fjord system, and indeed for other areas. Even within this restricted fjord system, the different branches of the fjord had their particular characteristics and also a significant change over the $5 \mathrm{~d}$ period between main samplings. Rather than supporting the generalization of a static picture as in Fig. 20, this suggests that the flow pattern for phosphate may be a sensitive indicator for changing dynamic states of the microbial food web.
Acknowledgements. Nutrient analyses on the autoanalyzer were done by $A$. Aadnesen and $M$. Hagebo. We also thank the crew of RV Hakkon Mosby for skilful assistance and $\mathrm{J}$. Dolan for helpful comments to the manuscript. This work was supported by the The Norwegian Research Council for Natural Sciences and the Humanities (NAVF), The Norwegian Research Council for Tecnical Sciences (NTNF). The Norwegian State Pollution Control in cooperation with Rogaland Fylkeskommune, and MAST-II project MEICE.

\section{LITERATURE CITED}

Ammerman, J. W., Azam, F. (1985). Bacterial 5'-nucleotidase in aquatic ecosystems: a novel mechanism of phosphorus regeneration. Science 227: 1338-1340

Ammerman, J. W., Azam, F. (1991a). Bacterial 5'-nucleotidase activity in estuarine and coastal marine waters: characterization of enzyme activity. Limnol. Oceanogr. 36 $1427-1436$

Ammerman, J. W., Azam, F. (1991b). Bacterial 5'nucleotidase activity in estuarine and coastal marine waters: role in phosphorus regeneration. Limnol. Oceanogr. 36: $1437-1447$

Azam, F., Smith, D. C. (1991). Bacterial influence on the variability in the ocean's biogeochemical state: a mechanistic view. In: Demers, S. (ed.) Particle analysis in oceanography. Springer Verlag, Berlin, p. 213-236

Aure, J., Rey, F. (1992). Oceanographic conditions in the Sandsfjord system, western Norway, after a bloom of the the toxic prymnesiophyte Prymnesium parvum Carter in August 1990. Sarsia 76: 247-254

Bengis-Garber, C. (1985). Membrane-bound 5'-nucleotidase in marine luminous bacteria: biochemical and immunological properties. Can. J. Microbiol. 31: 543-548

Bengis-Garber, C., Kushner, D. J. (1981). Purification and properties of 5 -nucleotidase from the membrane of Vibrio costicola, a moderate halophilic bacterium. J. Bacteriol. 146: $24-32$

Bengis-Garber, C., Kushner, D. J. (1982). Role of membranebound $5^{\prime}$-nucleotidase in nucleotide uptake by the moderate halophile Vibrio costicola. J. Bacteriol. 149:808-815

Bratbak, G., Heldal, M., Thingstad, T. F., Riemann, B., Haslund, O. H. (1992). Incorporation of viruses into the budget of microbial C-transfer. A first approach. Mar. Ecol. Prog. Ser, 83: 273-280

Bratbak, G., Thingstad, T. F. (1985) Phytoplankton-bacteria interactions: an apparent paradox? Analysis of a model system with both competition and commensalism. Mar. Ecol. Prog. Ser. 25: 23-30

Caron, D. A., Porter, K. G., Sanders, R. W. (1990). Carbon, nitrogen, and phosphorus budgets for the mixotrophic phytoflagellate Poteriochromonas malhamensis (Chrysophyceae) during bacterial ingestion. Limnol. Oceanogr. 35: $433-442$

Cembella, A. D., Anita, N. J., Harrison, P. J. (1984a). The utilization of inorganic and organic phosphorus compounds as nutrients by eucaryotic microalgae: a multidiciplinary perspective: part 1. CRC Crit. Rev. Microbiol. 10: 317-391

Cembella, A. D., Anita, N. J., Harrison, P. J. (1984b). The utilization of inorganic and organic phosphorus compounds as nutrients by eucaryotic microalgae: a multidiciplinary perspective: part 2. CRC Crit. Rev. Microbiol. 11. 13-81

Currie, D. J., Kalff, J. (1984). The relative importance of phytoplankton and bacterioplankton in phosphorus uptake in freshwater. Limnol. Oceanogr. 29: 311-321 
Cotner, J B., Wetzel, R. G. (1992). Uptake of dissolved inorganic and organic phosphorus by phytoplankton and bakterioplankton. Limnol. Oceanogr. 37: 232-243

DeHaan, H., Salonen, K. (1990). Abiotic transformations of iron and phosphate in humic lake water revealed by double-isotope labeling and gel filtration. Limnol. Oceanogr. 35: 493-497

Estep, K., Davis, P. G., Keller, M. D., Sieburth, J. McN. (1986) How important are oceanic algal nanoflagellates in bacterivory. Limnol. Oceanogr. 31:646-650

Flynn, K. J., Öpik, H., Syrett, P. J. (1986). Localization of the alkaline phosphatase and 5'-nucleotidase activities of the diatom Phaeodactylym tricornutum. J. gen. Microbiol. 132: $289-298$

Fox, L. E. (1989). A model for inorganic control of phosphate concentrations in river waters. Geochim. Cosmochim. Acta 53: $417-428$

Froelich, P. N. (1988). Kinetic control of dissolved phosphate in natural rivers and estuaries: a primer on the the phosphate buffer mechanism. Limnol. Oceanogr. 33: 649-668

Goldman, J. C., McCarthy, J. J., Peavey, D. G. (1979). Growth rate influence on the chemical composition of phytoplankton in oceanic waters. Nature 279: 210-215

Güde, H. (1990) Participation of bacterioplankton in epilimnetic phosphorus cycles of Lake Constance. Int. Ver. theor. angew. Limnol. Verh. 24: 816-820

Holm-Hansen. O., Riemann, B. (1978). Chlorophyll-a determination; improvements in methodology. Oikos 30: $438-447$

Jürgens, K. Güde, H. (1990). Incorporation and release of phosphorous by planktonic bacteria and phagotrophic flagellates. Mar. Ecol. Prog. Ser. 59: 271-284

Karl, D., Tien, G. (1992). MAGIC: a sensitive and precise method for measuring dissolved phosphorus in aquatic environments. Limnol. Oceanogr. 37: 105-116

Koroleff, F. (1976). Determination of phosphorus. In: Grasshoff, K. (ed.) Methods in seawater analysis. Verlag Chemie, Weinheim

Kaartvedt, S., Johnsen, T. M, Aksnes, D. L., Lie, U., Svendsen, H. (1991). Occurrence of the toxic phytopflagellate Prymnesium parvum and associated fish mortality in a Norwegian fjord system. Can. J. Fish. Aquat. Sci. 48: $2316-2323$

McComb, R. B., Bowers, G. N., Posen, S. (1979). Alkaline phosphatases. Plenum Press, New York

Nissen, H., Heldal, M., Norland, S. (1987). Growth, elemental composition, and formation of phosphate bodies in Vibrio natriegens cultures shifted from phosphate limited to phosphate-pulsed media. Can. J. Microbiol. 33: $583-588$

Paasche, E., Erga, S. R. (1988). Phosphorus and nitrogen limitation of phytoplankton in the inner Oslofjord (Norway). Sarsia 73: 229-243

Parslow, J. S., Harrison, P. J., Thompson, P. A. (1984). Saturated uptake kinetics: transient response of the marine diatom Thalassiosira pseudonana to ammonium. nitrate, silicate, or phosphate starvation. Mar. Biol. 83: $51-59$

This article was presented by F. Rassoulzadegan,

Villefranche-sur-Mer, France
Pengerud, B., Skjoldal, E. F., Thingstad, T F. (1987). The reciprocal interaction between degradation of glucose and ecosystem structure. Studies in mixed chemostat cultures of marine bacteria, algae, and bacterivorous nanoflagellates. Mar. Ecol. Prog. Ser. 35: 111-117

Porter, K. G., Feig, Y. S. (1980). The use of DAPI for identifying and counting aquatic microflora. Limnol. Oceanogr. 25: $943-948$

Perry, M. J. (1972). Alkaline phosphatase activity in subtropical Central North Pacific waters using a sensitive fluorometric method. Mar. Biol. 15: 113-119

Rosenberg, H., Gerdes, R. G., Chegwidden, K. (1977). Two systems for the uptake of phosphate in Escherichia coli. J. Bacteriol. 131: 505-511

Rothhaupt, K. O., Güde, H. (1992). The influence of spatial and temporal gradients on phosphate partitioning between different size fractions of plankton: further evidence and possible causes. Limnol. Oceanogr. 37: $739-749$

Sakshaug, E., Andersen, K., Myklestad, S., Olsen, Y (1983). Nutritional status of phytoplankton communities in Norwegian waters (marine, brackish, and fresh) as revealed by their chemical composition. J. Plankton Res. 5 : $175-196$

Shilo, M. (1967). Formation and mode of action of algal toxins. Bacteriol. Rev. 31: 180-193

Suttle, C. A., Fuhrman, J., Douglas, G. C. (1990). Rapid ammonium cycling and concentration dependent partitioning of ammonium and phosphate: implications for carbon transfer in planktonic communities. Limnol. Oceanogr. 35: $424-432$

Tamminen, T (1989). Dissolved organic phosphorus regeneration by bacterioplankton: 5'-nucleotidase activity and subsequent phosphate uptake in a mesocosm enrichment experiment Mar. Ecol. Prog. Ser. 58: 89-100

Taylor, W. D., Lean, D. R. S. (1981). Radiotracer experiments on phosphorus uptake and release by limnetic microzooplankton. Can. J. Fish. Aquat. Sci. 38: 1316-1321

Tett, P., Cottrell, J. C., Trew, D. O., Wood, B. J. B. (1975). Phosphorus quota and the chlorophyll: carbon ratio in marine phytoplankton. Limnol. Oceanogr. 20: 587-603

Thompson, L. M. M., MacLeod, R. A. (1974). Biochemical localization of alkaline phosphatase in a marine pseudomonad. J. Bact. 117: 819-825

Turk, V., Rehnstam, A.-S., Lundberg, E., Hagström, \&. (1992). Release of bacterial DNA by marine nanoflagellates, an intermediate step in phosphorus regeneration. Appl, environ. Microbiol. 58: 3744-3750

Vadstein, O., Jensen, A., Olsen, Y., Reinertsen, H. (1988) Growth and phosphorus status of limnetic phytoplankton and bacteria. Limnol. Oceanogr. 33: 489-503

Vadstein, O. Olsen, Y (1989). Chemical composition and phosphate uptake kinects of limnetic bacterial communities cultured in chemostats under phosphorus limitation. Limnol. Oceanogr. 34: 939-946

Wright, R. T., Hobbie, J. E. (1966). Use of glucose and acetate by bacteria and algae in aquatic ecosystems. Ecology 47 : $447-464$

Manuscript first received: November 16, 1992

Revised version accepted: April 10, 1993 